\title{
Sex Steroid Treatment of Constitutionally Tall Stature*
}

\author{
STENVERT L. S. DROP, WOUTER J. DE WAAL, AND \\ SABINE M. P. F. DE MUINCK KEIZER-SCHRAMA \\ Department of Pediatrics, Division of Endocrinology, Sophia Children's Hospital, Erasmus University, \\ 3000 CB Rotterdam, The Netherlands
}

I. Introduction

II. Normal vs. Extremes of Growth

A. Defining CTS

B. Endocrinology of CTS

III. Endocrinology of Bone Growth and Maturation

IV. Sex Steroid Action on Bone Growth and Maturation

V. Height Prediction

A. Skeletal maturity or BA

B. Computed assisted skeletal age-scoring systems

C. Accuracy of height prediction

D. New prediction equations in constitutionally tall children

VI. Treatment of CTS: General Concepts

VII. Treatment of Constitutionally Tall Boys
A. T treatment modalities
B. Height reduction
C. Effects on gonadal function
D. Other clinical effects

VIII. Estrogen Treatment in Tall Girls
A. Estrogen treatment modalities
B. Height reduction
C. Effects on gonadal function
D. Other adverse effects

IX. Alternative Treatment Modalities and Future Research

$X$. Conclusions and Recommendations

\section{Introduction}

$W^{1}$ HILE as many children grow above the 97th percentile (corresponding to +1.8 sDs) as below the 3rd percentile, tall stature is a far less common reason for seeking medical attention than short stature. Tall stature is more easily accepted in society and may even be an advantage. This holds specifically true for boys, and girls are more often referred.

Growth is a result of complex processes. Genetic constitution, nutrition, endocrine function, and psychosocial well being are all involved in the process of growth $(1,2)$. The genetic component of height has been estimated to be $0.5-0.9$, i.e., $50-90 \%$ of the height variation is accounted for by genetic factors. Assessment of the parental height as an indicator of

Address reprint requests to: Stenvert L. S. Drop, M.D., Ph.D., Division of Endocrinology, Sophia Children's Hospital, P.O. Box 2060, 3000 CB Rotterdam, The Netherlands. E-mail: drop@alkg.azr.nl

*This study was supported by 'Stichting Kinderpostzegels,' Leiden; 'Stichting Menselijke Voortplanting,' Rotterdam; and 'Sophia Stichting voor Wetenschappelijk Onderzoek,' Rotterdam. the genetic component of growth and development of the child is therefore of critical importance (3). In addition, socioeconomic factors such as social class, family size, birth rank, housing, and crowding are associated with growth. Improved socioeconomic conditions and better health have led to the manifestation of a positive secular trend in growth and development over the last centuries. In 1865 the mean adult height among Dutch army recruits was $165 \mathrm{~cm}$. One century later, in 1965, the mean adult height in boys was 178 cm. Fifteen years later, in 1980, the mean adult height had increased by another $4 \mathrm{~cm}$ to $182 \mathrm{~cm}$. In the middle of the 19th century, age of menarche of European girls was about 16-17 yr. Nowadays, the mean age of menarche is 13 yr or even less.

Phenomena responsible for both positive and negative secular trends have affected height throughout our history. Studies of fossil remains of our hominid ancestors demonstrate that the stature of individuals living during the last hundred-thousands of years reached the range of heights seen today: the mean stature of early anatomically modern Homo sapiens in Europe was $184 \mathrm{~cm}$ in males and $167 \mathrm{~cm}$ in females $(4,5)$. Thus, stature is based on many factors, including heredity and environment.

In recent years, information concerning auxology and (neuro)endocrinology of tall stature has expanded. In addition, long-term results of height-reducing treatment modalities have become available. In this review we will give an update of the (neuro)endocrinology, the auxology, the differential diagnosis, and the therapeutic modalities available in the management of constitutionally tall stature (CTS).

\section{Normal vs. Extremes of Growth}

\section{A. Defining CTS}

A thorough understanding of the factors influencing the process of normal growth is essential to understanding the pathophysiology of the extremes of growth (6). It has been well established that populations of various ethnic origin differ considerably in growth and development. Therefore, reference growth curves have been obtained by measuring healthy individuals longitudinally or cross-sectionally (or both). Extremes of growth can be defined knowing the normal variance of growth of the reference population. Usually an individual whose height differs more than 2 sDs from the population mean, i.e., a child with a height above the 97th percentile of the growth curve, is considered too tall just as a child growing below the 3rd percentile is considered too short. It should be emphasized, however, that most of the 
TABLE 1. Mean or median and +1.8 SD height $(\mathrm{p} 97)$ values $(\mathrm{cm})$ in various countries

\begin{tabular}{|c|c|c|c|c|c|}
\hline \multirow{2}{*}{$\begin{array}{l}\text { Country (year of } \\
\text { ascertainment) }\end{array}$} & \multicolumn{2}{|c|}{ Height (boys) } & \multicolumn{2}{|c|}{ Height (girls) } & \multirow{2}{*}{ Reference } \\
\hline & Mean or median & $(+1.8 \mathrm{sD} / \mathrm{p} 97)$ & Mean or median & $(+1.8 \mathrm{sD} / \mathrm{p} 97)$ & \\
\hline The Netherlands (1985) & 182.0 & 194.5 & 168.3 & 179.8 & 7 \\
\hline Germany (1992) & 179.9 & 192.5 & 167.0 & 179.0 & 8 \\
\hline Sweden (1976) & 179.1 & 192.4 & 165.5 & 178.2 & 9 \\
\hline Czechia (1993) & 178.3 & 191.7 & 165.0 & 176.8 & 10 \\
\hline Denmark (1982) & 179.4 & 190.4 & 166.0 & 176.0 & 11 \\
\hline United Kingdom (1995) & 176.4 & $190.5^{a}$ & 163.6 & $176.0^{a}$ & 12 \\
\hline USA (NHCS) (1977) & 176.8 & $187.6^{b}$ & 163.7 & $173.6^{b}$ & 13 \\
\hline France (1979) & 175.0 & 187.0 & 163.0 & 174.5 & 14 \\
\hline Mexico (1975) & 172.8 & 186.3 & 160.6 & 174.5 & 15 \\
\hline Turkey (1978) & 173.5 & 186.0 & 160.0 & 171.0 & 16 \\
\hline Argentina (1987) & 172.8 & 185.6 & 160.7 & 172.2 & 17 \\
\hline Korea (1979) & 170.2 & 180.0 & 157.6 & 166.5 & 18 \\
\hline
\end{tabular}

${ }^{a} \mathrm{p} 98$.

${ }^{b} \mathrm{p} 95$.

children who grow beyond these percentiles are part of a continuum of a normal distribution curve, and only a minority will have a defined abnormality.

CTS is defined as a condition in which the height of an individual is 2 sDs above the corresponding mean height for a given age, sex, and population group. As shown in Table 1 , height p97 values vary substantially among various populations. The Scandinavians and the Dutch are among the tallest people in the world.

In CTS, usually one or both parents are tall; thus, genetic and familial factors are most important etiologically. Mean birth length is in the 75th percentile, and tall stature becomes evident at the age of 3-4 yr. Growth velocity is accelerated in early childhood but slows down after $4-5$ yr of age when the growth curve starts to parallel the normal curves (19).

The diagnosis is generally made from the family history of growth and from physical examination. No apparent abnormalities are present at physical examination, which permits distinction from excessive growth syndromes such as Marfan syndrome and Klinefelter syndrome (see Table 2).

TABLE 2. The differential diagnosis of tall stature

A. Variants of normal growth: constitutionally (familial) tall stature

B. Primary growth disorders

1. Sex-chromosome related disorders

Klinefelter syndrome and variants

XXY syndrome

XYY syndrome

2. Overgrowth syndromes with advanced bone maturation

Sotos syndrome

Weaver syndrome

Marshall-Smith syndrome

Beckwith Wiedemann syndrome

Hyperinsulinism

3. Syndromes with tall stature as outstanding feature

Marfan syndrome

Marfanoid phenotype

MEN IIB

Hemocysteinuria

Estrogen inactivity/resistance

C. Secondary growth disorders

GH excess

Precocious (pseudo) puberty

MEN IIB, Multiple endocrine neoplasia IIB.

\section{B. Endocrinology of CTS}

A significant positive correlation has been established between growth and GH secretion in studies of children with various heights (20-22). In a recent study, insulin-like growth factor (IGF-I) levels in prepubertal children correlated significantly with height velocity in the following year (23). In CTS children, relatively high levels of IGF-I were measured (24).

At the time of puberty GH secretion increases. Sex-specific changes regarding the timing of the pubertal increase of $\mathrm{GH}$ secretion during puberty have been found by analyzing $24-\mathrm{h}$ GH profiles in healthy boys and girls (25). This increase, occurring about $1 \mathrm{yr}$ earlier in girls than in boys, is correlated to estradiol levels in both boys and girls $(26,27)$. Similarly, serum levels of IGF-I rise at puberty (23). In boys with delayed puberty, testosterone $(\mathrm{T})$ treatment caused increased GH pulse amplitude, thereby increasing the mean serum GH concentration. T exerts its effect on GH via an estrogendependent mechanism by increasing hypothalamic GHRH release (28). Paradoxical GH responses to glucose loading and to administration of TRH or GHRH, similar to those seen in acromegaly, have been observed in some CTS children (29-31). However, these observations have not been substantiated in studies properly controlled for age and stage of puberty. Tauber et al. (32) showed a clear heterogeneity of GH secretion in tall children, with some of them even having low GH secretion (32). Therefore, abnormal responses may be related more to the stage of puberty of the child than to abnormalities of GH secretion (33).

In conclusion, constitutionally tall children are healthy children without hard evidence of pathology of the GH-IGF-I axis.

\section{Endocrinology of Bone Growth and Maturation}

Given that stature of patients with CTS appears to have a genetic basis, it is worthwhile to review the biological factors known to regulate normal skeletal growth. This information is relevant in the context of the current treatment modalities of CTS, which are based on sex steroid action on bone growth and maturation (see below). 
Longitudinal bone growth is the result of expansion of the growth plate cartilage. As puberty proceeds, a progressive decrease in cartilage expansion occurs. Because the vascular invasion and resorption of calcified cartilage by chondroclasts exceeds cartilage expansion, there is a progressive thinning of the growth plate. Ultimately, the growth plate becomes perforated and longitudinal bone growth ceases (34, 35).

The regulation of longitudinal bone growth is very complex, and several factors, including nutritional, endocrine, paracrine, and autocrine, are necessary (36). For normal bone growth and maturation the gonadal steroids are essential in conjunction with several hormones and growth factors:

1. GH. GH has been shown to stimulate long bone growth in a dose-dependent fashion. At the cellular level GH interacts with the GH receptor. The expression of $\mathrm{GH}$ receptors is developmentally regulated in epiphyseal chondrocytes (37). There is ample evidence that GH interacts directly with cells of the growth plate and not only through IGF-I (vide infra). Green and associates (38) have proposed the dual effector theory based on in vitro observations (see also Ref. 39). This theory states that GH is a prerequisite of cartilage maturation. Priming of resting chondrocytes in the growthplate by $\mathrm{GH}$ is required for IGF-I to promote 'clonal expansion' of growth plate chondrocytes and to stimulate skeletal growth. More recently it has been suggested that this theory may not apply to the in vivo situation. The presence of GH receptors is not limited to resting chondrocytes. It was shown that both IGF-I and GH exerted their effect at each stage of differentiation rather than acting specifically upon particular subpopulations of cells at certain phases of chondrocyte differentiation (40). The observation that GH-overproducing transgenic mice have a significantly larger size than their controls, while IGF-I transgenic mice have a normal size, would support the theory of a differential effect of GH and IGF.

However, transgenic models are inadequate for studying the independent actions of IGF-I and GH as in IGF-overproducing transgenic mice GH production is not completely suppressed (41).

2. Thyroid hormone. Thyroid hormones are crucial for bone growth because of their direct effects on bone. In addition, there are indirect effects by stimulating pituitary GH release (42), thereby increasing serum IGF-I levels. Lastly, effects of thyroid hormone on IGF-I generation by chondrocytes have been demonstrated (43). The obvious experiment of nature is represented by the syndrome of resistance to thyroid hormone hallmarked by short stature and marked delayed bone maturation (44).

3. Vitamin D. In addition to the crucial role of vitamin D in bone mineralization, several observations point to a possible role in chondrocyte proliferation and bone growth. In rats, proliferation of growth plate chondrocytes is decreased by high doses and increased by low doses of 1,25-dihydroxyvitamin $\mathrm{D}_{3}\left[1,25-(\mathrm{OH})_{2} \mathrm{D}_{3}\right](45)$. Moreover, short stature and delayed bone maturation may be present in the syndrome of vitamin D resistance (46).
4. Growth factors. As IGF-I and -II are among the most prevalent growth factors secreted by skeletal cells and have important actions on bone formation, it is reasonable to predict that they play a significant role in bone growth and maturation. In the circulation IGF-I and -II form a complex with IGF-binding proteins, and there is little, if any, free IGF-I or -II available in bone. Thus, locally secreted IGF-I and -II acting in a paracrine or autocrine manner might play an even more important role in the regulation of growth plate cell function. IGFs enhance the differentiated function of the osteoblast and increase collagen synthesis. Moreover, IGFs decrease collagen degradation and IGF-I (but not IGF-II) increases osteoclast recruitment (41).

The synthesis of IGF-I and -II takes place in cells of osteoblast lineage and is controlled by systemic hormones (stimulatory: PTH, GH, estrogens; inhibitory: cortisol, vitamin D) and local factors (stimulatory: bone morphogenetic proteins, $\mathrm{PGE}_{2}$; inhibitory: fibroblast growth factor, transforming growth factor, platelet derived growth factor).

In addition, skeletal cells synthesize a variety of IGF-binding proteins (IGFBP). They act to regulate and modulate the local actions of IGFs. Most IGFBPs have been shown to have inhibitory effects on either IGF-I or -II. However, IGFBP-5 has been shown to potentiate IGF-II action on osteoblast- derived cell lines (47).

\section{Sex Steroid Action on Bone Growth and Maturation}

The pubertal growth spurt has long been considered to be an androgen-dependent process. However, there is abundant clinical and experimental evidence showing that estrogens may be primarily responsible for accelerated growth during puberty (48). It is remarkable that peak height velocity occurs in girls and boys when estradiol levels are not only low but also quite similar $(49,50)$. Still, a direct relationship between levels of $\mathrm{E}_{2}, \mathrm{GH}$, and pubertal growth has not been established $(51,52)$.

Girls with Turner syndrome show a growth spurt during estrogen replacement therapy (53-55). Similarly, girls with central or pseudo-precocious puberty with clearly elevated estrogen levels show increased height velocity and premature epiphyseal closure (56). Whereas in patients with androgen insensitivity syndrome the growth spurt resembled that of women both in magnitude and timing, mean final adult height was taller than in normal women but shorter than in normal men $(22,48,57)$. This would suggest that $Y$ chromosome-related factors contribute to stature. Patients with familial male precocious puberty treated with antiandrogens alone did not revert to a normal prepubertal growth rate but only when an aromatase inhibitor was added (58).

Studies of acute infusion of gonadal steroids in peripubertal children have illustrated the complexity of the relationship between gonadal steroids and the GH/IGF axis (49, $59,60)$. These studies suggest sex differences in the control of $\mathrm{GH}$ secretion in the response to $\mathrm{E}_{2}$ during puberty. Moreover, acute and chronic $\mathrm{E}_{2}$ exposure may have different effects: acute infusions decrease whereas prolonged exposure may increase GH bioactivity (60). 
There is also evidence for a dose dependency as high doses of estrogens result in decreased growth velocity in both males and females $(58,61,62)$. High-dose estrogen treatment decreased IGF-I levels in acromegalic patients as well as in tall girls $(63,64)$. Recently, a man was described with estrogen resistance. He had a normal prepubertal growth and normal timing of onset of secondary sex characteristics. Despite full masculinization he continued to grow. At $18 \mathrm{yr}$ his height was $204 \mathrm{~cm}$, and the growth velocity was $1 \mathrm{~cm} / \mathrm{yr}$. The bone maturation and mineralization were both markedly retarded (65). Moreover, a phenotypic female with aromatase deficiency was described showing markedly delayed bone maturation (66). It is well known that in boys with pseudo-precocious puberty as a result of congenital adrenal hyperplasia, height velocity is increased and epiphyseal maturation is advanced, resulting in stunted adult height. There is ample evidence that androgen-stimulated growth is largely based on influencing GH release and augmentation of IGF-I. However, it is not excluded that these effects are estrogen mediated. On the other hand, nonaromatizable androgens have growth-promoting effects not mediated via GH-IGF-I axis (67). Keenan et al. (68) reported that nonaromatizable DHT induced and maintained accelerated growth rate in short boys with delayed puberty in spite of a 50\% decline in integrated GH concentration and no change of IGF-I level, suggesting that strictly androgen-mediated skeletal growth might be exerted locally in growing cartilage.

In vitro studies using rat- and human-derived cells have shown that there might be a sex-specific and age-dependent responsiveness of cartilage and bone cells to sex steroids. Cells and tissues derived from males respond primarily to $\mathrm{T}$, whereas cells and tissues derived from females respond primarily to estrogen. The best response was obtained in tissue from children in early puberty (69-71). The mechanism of action of the gonadal steroids on growth plate cartilage is poorly understood. The effect of estrogens on proliferation of human chondrocytes in vitro was shown to be biphasic: at low concentration a stimulatory effect was observed, while at supraphysiological doses inhibition was observed.

High doses of estrogens stimulate the maturation of cartilage without increasing the growth rate: cell division by cartilage cells is inhibited in the proliferative zone of the growth plate, and the age-related decrease in size of the hypertrophic chondrocytes is accentuated by estrogens (7276). The latter effects were not overcome by the addition of GH or IGF, suggesting that estrogens may act directly on chondrocytes or may influence the release of factors that inhibit cell proliferation locally (77). Using fetal rat osteoblasts in culture, McCarthy et al. (78) established that estrogens do not alter IGF-I promotor activity but inhibit the biological effects of all hormones that act through cAMP to regulate skeletal IGF-I expression and activity.

Collectively, bone growth and bone maturation are the result of a complex interplay of various hormones in which $\mathrm{GH}$ and the gonadal steroids have a pivotal role. Moreover, there might be a sex-specific and age-dependent responsiveness of cartilage and bone cells to sex steroids. At the level of the growth plate, estrogen receptor-mediated processes appear essential in expressing the effects of sex steroids.

\section{Height Prediction}

Height prediction plays a key role in the management of children with growth disorders and consequently in children with CTS. Therapeutic intervention is based on the estimated height prognosis: whenever the height prognosis exceeds a certain limit (usually 2 sDs above the mean of the population), treatment might be considered. Hence, accurate techniques for reliable height predictions are essential. The suitability and importance of skeletal maturity as a predictor variable for adult height have long been recognized (79-82). The techniques of Tanner-Whitehouse and Bayley-Pinneau both share the use of bone age (BA) as an indicator of skeletal maturity to estimate final adult height. The first prediction method uses the BA method developed by Tanner et al. (80), whereas the latter utilizes the BA method of Greulich and Pyle (83). Each BA determination is linked with potential problems as briefly summarized below (84).

\section{A. Skeletal maturity or BA}

A measure of skeletal maturity is generally obtained by assessing the appearance and shape of the bones of the hand and wrist on an x-ray. These appearances change with age, and their rate of change is a direct measurement of the rate of maturation. Various methods of evaluation of BA and maturity have been developed over the years. The methods most commonly used are the Greulich and Pyle Atlas (83) and the Tanner-Whitehouse (TW2) method $(79,80)$. In addition, other methods such as the FELS-method are also available (85).

The method of Greulich and Pyle for BA estimation is presented as an atlas of examples of radiographs of the left hand and wrist of healthy children at various ages (83). The children who form the standard group were drawn from the Brush Foundation Study, which selected children from the better socioeconomic strata in Cleveland, Ohio, from 1930 onward. All the children were white, had been born in the United States, and were of North European ancestry. Each of the standards of the atlas was selected from a large number of children of the same sex and age. All films were arranged in order of increasing maturity, and the film chosen as the standard is the one most representative of the central tendency or anatomical mode. The BA is determined by comparison with the standards.

The Tanner-Whitehouse technique describes maturity indicators for each bone of the hand and wrist $(79,80)$. Each bone progresses through a series of specific stages with assigned weighted scores. These scores are added to form a maturity score, which in turn can be converted to a corresponding BA. The source data for this method were obtained from large groups of British children of an average socioeconomic level in the 1950s.

The major problem in both techniques is that subjective processes and discontinuous scales are used that result in considerable inter- and intrarater variability in BA $(84,86-$ 88). In a direct comparison, the BA as determined by the Greulich and Pyle method is generally about 1 'year' less than that as assessed by the Tanner-Whitehouse technique $(86,87$, 89). One should realize, however, that BA determinations are 
estimates of maturity and that, in fact, there is no objective quantification available. Recently, various authors have discussed the main problems of skeletal maturation assessment and the sources of possible bias (90-92). Therefore, it is mandatory that one is acquainted with the specific qualities of the BA determination method used.

\section{B. Computed assisted skeletal age-scoring systems}

As stated above, estimates of BA do not advance smoothly as the child matures but in a saltatory fashion. In the TW2 system, a difference of one stage in the rating of a particular bone may result in an increase of 0.3 'years' in BA. In actuality, skeletal maturity will advance gradually. To diminish the errors in the interpretation of maturity and to improve BA ratings, the TW2 system has been transformed recently by the original author into a computerized image analysis system using a continuous scale Computer-Assisted Skeletal Age System: CASAS $(93,94)$. So far, a limited number of studies have been performed on the reliability and validity of CASAS in healthy children and in children with tall stature (95-97). Results indicate that reliability of the CASAS ratings is extremely high, both within and across operators. Moreover, in longitudinal series, BA does advance far more smoothly compared with manual scores. With regard to children with tall stature, CASAS was found quite applicable. The CASAS method, however, is not without drawbacks and is still, to some extent, user dependent. Further developments are needed to improve these aspects.

\section{Accuracy of height prediction}

Prediction methods that have survived the tests of clinical usefulness are those that incorporate a multitude of variables relating to adult height and maturity and that are sensitive in their assessment of childhood maturity (82). Most prediction methods are based on growth data of unselected normally growing children. Therefore, when applied to children with tall stature, critical appraisal of their qualities is required. Knowledge concerning the specific advantages and disadvantages of the various methods is of utmost importance since it may influence possible therapeutic intervention.

Thus far, only a limited number of studies have been performed testing the reliability of height prediction methods in large groups of untreated children with tall stature. The accuracy of height prediction may be expressed math- ematically as the difference between predicted adult height and actual adult height. In this way, positive values indicate overestimation, and negative values reflect underestimation of the final adult height. Absolute errors demonstrate the method's overall predictive error and is not influenced by over- or underestimation.

Table 3 summarizes the accuracy of various prediction methods in boys with tall stature (98-101). The systematic tendency of the prediction methods to over- or underestimate final adult height are not consistent. Variation in initial clinical data (CA and BA) and time definition of reaching adult height may account for this inconsistency. In general, however, the method of Bayley-Pinneau tends to overestimate final height, whereas the method of Tanner-Whitehouse slightly under- or overestimates final height. Joss et al. (102) described a systematic overprediction of the BayleyPinneau technique in a study of 32 tall boys. In addition, they reported a systematic overprediction using the TannerWhitehouse method, which was even more pronounced at an older BA. Some investigators have used repeated predictions in the same subject for accuracy assessment. This may have induced bias in reported means and/or standard deviations of the errors of prediction. When the group of patients was divided into age-specific subgroups it appeared that with increasing age both methods became more accurate in predicting adult height $(100,101)$. In our study the Index of Potential Height (IPH) based on the BA of Greulich and Pyle was found to be the most reliable method as it showed the lowest mean error and mean absolute error, $-0.1(2.9) \mathrm{cm}$ and $2.3(1.8) \mathrm{cm}$, respectively (101). The IPH is based on the assumption that the height SD scores for BA [rather than for chronological age (CA)] remains constant up to final height.

The accuracy of height prediction methods in girls with tall stature is given in Table 4 (64, 101, 103-109). Again, inconsistency is present in reported errors of prediction, probably due to differences in initial clinical data and timing of adult height assessment. Nevertheless, the mean errors are found to be rather small, indicating that height prediction in tall girls is quite accurate regardless of which method is used. As in boys, predicting adult height became more accurate with increasing age (101). The mean absolute errors were also small, a confirmation of their reliability. It seems that there is no 'best' prediction method in tall girls; the choice of method for use in daily practice may therefore depend on the preference and experience of the clinician.

TABLE 3. Mean error of prediction (cm) of the Bayley-Pinneau and Tanner-Whitehouse method in untreated constitutionally tall boys (prediction minus actual height)

\begin{tabular}{|c|c|c|c|c|}
\hline \multirow{2}{*}{ Study } & \multirow{2}{*}{ Number of patients } & \multicolumn{2}{|c|}{ Prediction method (SD) } & \multirow{2}{*}{ Reference } \\
\hline & & Bayley-Pinneau & $\overline{\text { Tanner-Whitehouse }}$ & \\
\hline Zachmann et al. & 8 & +2.3 & $+0.02(3.7)$ & 98 \\
\hline Brämswig et al. & 9 & $+1.7(4.5)$ & $+1.1(4.4)$ & 99 \\
\hline \multirow[t]{2}{*}{ Brämswig et al. } & 42 & $+2.1(4.8)$ & $+0.6(5.4)$ & 100 \\
\hline & & $\begin{array}{c}\text { Absolute error } \\
4.0(3.3)\end{array}$ & $\begin{array}{c}\text { Absolute error } \\
4.2(3.3)\end{array}$ & \\
\hline \multirow[t]{2}{*}{ De Waal et al. } & 55 & $+2.8(3.6)$ & $-0.9(4.8)$ & 101 \\
\hline & & $\begin{array}{c}\text { Absolute error } \\
3.3(3.1)\end{array}$ & $\begin{array}{c}\text { Absolute error } \\
3.9(2.9)\end{array}$ & \\
\hline
\end{tabular}


TABLE 4. Mean error of prediction (cm) of the Bayley-Pinneau and Tanner-Whitehouse method in untreated constitutionally tall girls (prediction minus actual height)

\begin{tabular}{|c|c|c|c|c|}
\hline \multirow{2}{*}{ Study } & \multirow{2}{*}{ Number of patients } & \multicolumn{2}{|c|}{ Prediction method (SD) } & \multirow{2}{*}{ Reference } \\
\hline & & Bayley-Pinneau & Tanner-Whitehouse & \\
\hline Zachmann et al. & 9 & & $+0.4(3.8)$ & 103 \\
\hline Reeser et al. & 14 & -0.8 & +0.1 & 104 \\
\hline John and Schellong & 18 & $+1.3(2.5)$ & $+0.7(2.5)$ & 105 \\
\hline Schambach and Nitschke & 26 & $-0.5(2.5)$ & & 106 \\
\hline Bartsch et al. & 23 & $0.6(2.2)$ & & 107 \\
\hline Svan et al. & 12 & $+1.2(1.5)$ & & 64 \\
\hline Ignatius et al. & 28 & $\begin{array}{l}-0.9 \\
-1.0 \\
+0.8\end{array}$ & & 108 \\
\hline Joss et al. & 21 & $+2.4(2.9)$ & $+1.3(2.8)$ & 109 \\
\hline \multirow[t]{2}{*}{ De Waal et al. } & 88 & $+0.5(2.7)$ & $-0.8(3.1)$ & 101 \\
\hline & & $\begin{array}{c}\text { Absolute error } \\
2.0(1.9)\end{array}$ & $\begin{array}{c}\text { Absolute error } \\
2.3(2.2)\end{array}$ & \\
\hline
\end{tabular}

TABLE 5. Regression equations based on samples of untreated constitutionally tall children

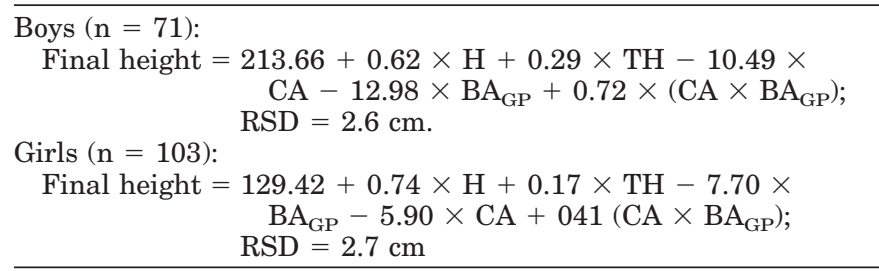

H, Height; TH, target height.

\section{New prediction equations in constitutionally tall children}

As stated above, for children growing at the upper extremes of normal, i.e., beyond +2 sD above the mean of the normal population, it seems far better to use prediction models based on growth data derived from a sample of tall children. For this reason Tanner and co-workers revised their original equations (Mark 1) (79) by including numbers of very tall (and very short) children in the new source sample in the standardizing group (Mark 2) (80). Unfortunately, only tall girls had been included. This might explain the finding of Cameron et al. (110) that the accuracy of prediction in tall boys did not improve comparing the older TW Mark 1 method with the revised TW Mark 2 method.

To improve height prediction in children with constitutionally tall stature, we developed regression equations based on growth data derived from a sample of untreated tall children (55 boys/88 girls) (111). Since the quality of a regression model is reflected in its residual standard deviation (RSD), the smaller the RSD the better the model predicts the dependent variable (final height) by the combination of predictor variables. In our newly developed prediction equations the RSD was $2.5 \mathrm{~cm}$ for both boys and girls (see Table 5). This implies that about $95 \%$ of the predictions lie within approximately $5 \mathrm{~cm}$ of the real value ( $\pm 2 \mathrm{RSD})$. From a clinical point of view, this inaccuracy is quite acceptable. In comparison, Tanner et al. (79) reported RSD values up to 4.1 $\mathrm{cm}$ in boys and $3.6 \mathrm{~cm}$ in girls for the same age ranges. The prediction equations were tested on a separate sample of 32 tall children (16 boys/16 girls) and compared with other prediction techniques including the TW Mark 2 and Bayley-
Pinneau method. The absolute errors of our prediction equations were smaller (though not reaching statistical significance) than the TW Mark 2 method and the Bayley-Pinneau technique, indicating less variability. These results give support to the idea that height prognosis in children with excessive growth is more accurate when based on growth data derived from tall children.

In conclusion, although prediction techniques may have small mean errors of prediction, it must be emphasized that considerable errors in height prognosis may be made in individual cases. This is reflected by the presence of the relatively large SDs of the mean errors of the prediction method applied. It is preferable, therefore, to give predicted adult height as a height with a confidence limit (using the residual SDS of the prediction technique for calculation).

\section{Treatment of CTS: General Concepts}

Treatment of tall stature is generally based on psychological grounds. From a strict medical point of view, there is no reason for treatment. Therefore, the validity and necessity for treatment are questionable. Although psychosocial factors form the main reason for treatment, extensive psychological investigation before or during height reductive therapy has never been performed. Nevertheless, psychological problems in tall adolescent girls and boys have been recognized by pediatricians and endocrinologists (112-115). A commonly voiced concern is that these children feel different from their peers and that they are subject to hurtful remarks about their height. As a consequence, coping mechanisms such as kyphotic posture, social withdrawal, and even depression have been observed. Fear about future compatible partners (especially in girls) and career planning are also frequently reported problems (112-115). Practical problems for adolescents and adults alike might arise concerning clothing and shoes. Concurrent orthopedic problems, such as kyphosis or scoliosis, could make treatment desirable for purely mechanical reasons. A study of determinants of future trunk abnormalities in a cohort of 11-yr-old schoolchildren suggested that in addition to the onset of the adolescent growth spurt and the menarche, tall stature was positively associated with the incidence of adolescent idiopathic scoliosis and trunk abnormalities $(116,117)$. 
Sex steroids have been used in the treatment of tall boys and girls since the late 1950s. The basis for the use of sex hormones to limit adult height came from observations in children with (pseudo-) precocious puberty. These children show early closure of the epiphyses due to premature production of gonadal steroids, which limits their eventual adult height $(118,119)$.

Studies mainly in children with gonadal dysgenesis have suggested a biphasic dose-dependent effect of estrogens on growth rate, low dose having a stimulatory and high dose an inhibitory effect $(36,120,121)$. Furthermore, it has been demonstrated that the administration of high doses of gonadal steroids, specifically estrogens, accelerate bone maturation $(98,99,103,104,112,122-125)$. Since the first study in 1956, many reports have appeared describing the height-reducing effect of administration of high doses of sex hormones in girls $(64,103-109,112,122-131)$ and in boys $(98,99,132)$.

\section{Treatment of Constitutionally Tall Boys}

\section{A. T treatment modalities}

The effect of treatment with supraphysiological doses of $\mathrm{T}$ in reducing adult height in boys appears to be different from the effect of high doses of estrogens in girls. In T-treated tall boys, height velocity is not decreased and even increased in the early stages of puberty, whereas in estrogen-treated girls a decrease in growth velocity is observed (62).

It is generally agreed that the steroid hormone effects on bone maturation are due to an indirect action mediated by the GH/IGF-I axis combined with a direct effect at tissue level after metabolic conversion into estrogens (48).

The choice of the androgen preparation is unambiguous. 'Natural' compounds are preferred over 17-alkylated compounds as it has been observed that the latter may cause cholestasis and hepatic tumors and may negatively influence lipoprotein levels (115). The doses of the long-acting T esters (such as $\mathrm{T}$ propionate, enanthate, and decanuate) used in most studies are about $500 \mathrm{mg} / \mathrm{m}^{2} / \mathrm{month}$, which correspond to roughly 4 times the normal $\mathrm{T}$ production rate of adult men or to about 8-10 times that of early adolescence. In clinical practice, two weekly im injections of $500 \mathrm{mg}$ or 250 mg once a week are used. Whether such high doses are really necessary to obtain a maximum effect on bone maturation is not known. However, treatment with $\mathrm{T}$ at a mean dosage of $265 \mathrm{mg} / \mathrm{m}^{2} /$ month resulted in a lower BA velocity and thereby less reduction of adult height in a small group of tall patients with hypogonadotropic hypogonadism (98). Theoretically, an alternative treatment modality is testosterone undecanoate. Testosterone undecanoate in oleic acid is administered orally and is absorbed preferentially through the lymphatics into the bloodstream bypassing first-phase degradation in the liver (133). However, dose frequency is 2-3 times a day, and circulating blood levels tend to vary substantially (134). Dose finding studies for CTS treatment have not been performed.

\section{B. Height reduction}

The 'uncorrected' effect of height reductive therapy, i.e., height prediction minus achieved adult height, varies with the prediction method applied. Since every single prediction method has its own prediction error, the mean effect may be 'corrected' by subtraction of the corresponding mean prediction errors $(98,99,132)$ (see Table 6$)$. In our own studies the Bayley-Pinneau prediction showed the greatest mean 'corrected' effect of $2.0 \mathrm{~cm}$, while the IPH, being the most accurate method, calculated a mean 'corrected' effect of only $0.6 \mathrm{~cm}$ (101). An important finding, however, was that at the time of referral the control groups (tall boys and girls) were significantly different from children who had received sex hormone therapy. The proper 'net' treatment effect on final height was calculated by multiple linear regression analysis adjusting for differences in age, BA, and height prediction between treated and untreated children. The mean adjusted effect for the various prediction methods varied from -1.7 to $+0.7 \mathrm{~cm}$ in boys. There was, however, a marked variation in the individual height-reducing effect, ranging from -2.6 to $+15.8 \mathrm{~cm}$. Figure 1 shows the adjusted effect of therapy according to the IPH-Greulich-Pyle prediction and its 95\% confidence interval.

These outcomes are clearly less than the 'corrected' reductions of $4.7-7.5 \mathrm{~cm}$ previously reported $(98-100,132)$. In addition to the variability in adult height prediction methods as discussed above, these conflicting results may be due to differences in study design, comparability of the control group, inclusion criteria (such as age and BA at start of therapy), and therapeutic regimen. Furthermore, differences in CA at the time of final adult height was measured, and differences in BA at the time of cessation of therapy are important contributing factors.

It has been clearly shown that height reduction was dependent on the BA at start of therapy: height reduction was more pronounced when treatment was started at a younger BA $(100,101,132)$. However, an important issue that caused a significant reduction in the height-limiting effect was the observation of a marked additional posttreatment growth after cessation of therapy. This posttreatment growth might partly be explained by late-pubertal completion of spinal growth. On the other hand, the additional growth could result from the fact that treatment had been stopped before complete closure of the epiphyses. A significant negative relationship between posttreatment growth and BA at the time of stopping therapy $(r=-0.53 ; P<0.001)$ was observed (101). The latter contrasts with the opinion of Brämswig and co-workers (132), who advocated short-term therapy and reported significant height reduction (uncorrected: $7.6 \mathrm{~cm}$ ) with a mean BA (SD) of 15.3(0.8) yr at the time of stopping therapy. However, these results seem too optimistic, since final height assessment was performed at a relatively young mean (bone) age. Moreover, others failed to show any height reducing effect using the same therapeutic strategy, but with assessment of final height at a definite later point in time (135).

As illustrated in Fig. 1, when therapy was started at a BA of $14 \mathrm{yr}$ or older, adult final height significantly exceeded height prognosis at the time of start of treatment. This suggests that treatment had resulted in induction rather than reduction of growth. 


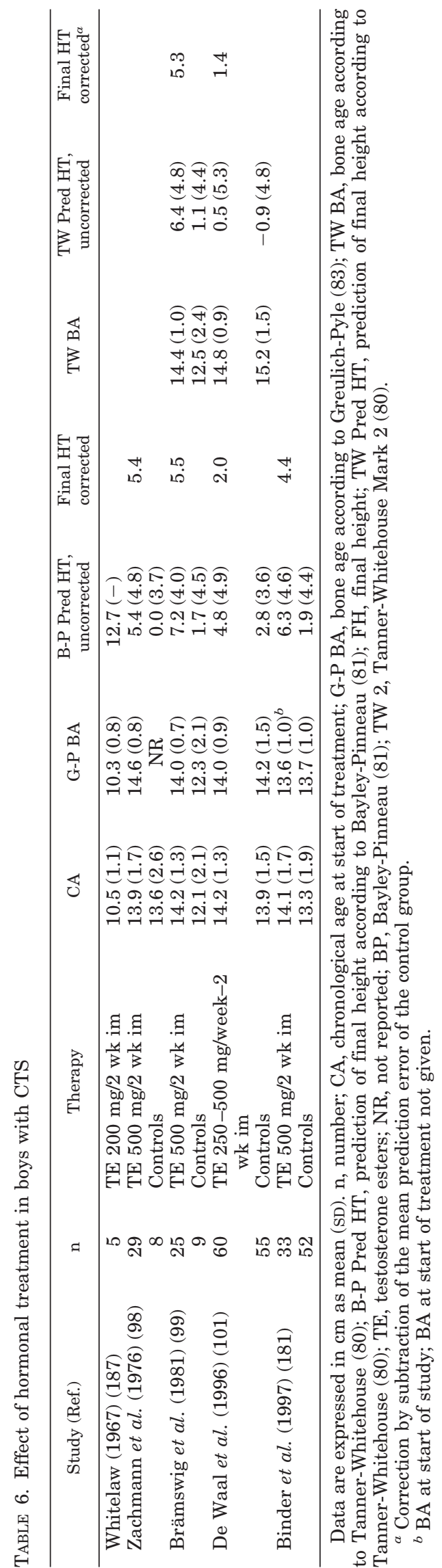

\section{Effects on gonadal function}

High doses of $\mathrm{T}$ induce suppression of the hypothalamopituitary-gonadal axis $(113,136)$. Contraceptive studies in adult men have shown that androgen-induced suppression of gonadotropins and of spermatogenesis is reversible (137, 138). However, extrapolation of these data to the management of tall stature in pubertal boys must be viewed with caution since factors that regulate spermatogenesis in normally functioning adult testes may not be the same as during puberty (139). Androgen therapy in tall boys is usually initiated at the first signs of puberty, and it is in this peripubertal period that important maturational changes take place in the testis (139-144). Influenced by complex hormonal actions, these maturational processes eventually lead to initiation of spermatogenesis. Onset of spermatogenesis (spermarche) as detected by urine analysis (spermuria) appears to be an early pubertal event: the median age of spermarche has been estimated to be 13-14 yr (145-148). In addition, it is noteworthy that administration of $\mathrm{T}$ esters at high doses may cause morphological and cytological changes, as shown in rat and human adult testes (149-151).

1. Plasma hormone levels. High T levels are obtained during treatment with supraphysiological doses of androgens suppressing the hypothalamo-pituitary-gonadal axis (152).

Zachmann, Prader, and co-workers $(98,113)$ reported a slow recovery of pituitary gonadotropins during LHRHstimulation tests after discontinuation of $\mathrm{T}$ therapy. Brämswig et al. (136) demonstrated normalization of gonadotropin levels in 100 tall boys after discontinuation of treatment with follow-up periods up to 48 months, although transient hypergonadotropic LH- and FSH- secretory patterns were observed. In a recently published study by the same group (153), hormonal levels and testicular function were evaluated after a follow-up period of approximately $10 \mathrm{yr}$ and compared with normal volunteers. Mean values of LH, FSH, PRL, $\mathrm{T}$, estradiol, and sex hormone-binding globulin were in the normal range in both groups. T was lower and FSH was higher in treated tall men compared with volunteers, but the only statistically significant difference was for T. We observed different levels of gonadotropins in previously treated tall men compared with controls (tall and 'normal' men) (154). Androgen-treated tall men had significantly higher FSH levels compared with controls. Levels of plasma hormones were not significantly correlated with parameters of sperm quality; however, we observed significant negative correlations between plasma FSH levels and sperm concentration as well as the age at start of therapy in the androgentreated men. We speculate that the higher levels of FSH may reflect intratesticular changes due to androgen treatment received during a period of testicular maturation especially during the earlier pubertal stages (155). These increased FSH levels may compensate for partially disturbed germinal function to maintain normal sperm quality (156). In a subgroup of previously treated and untreated men, we also measured inhibin B, which probably is a more direct marker of spermatogenesis than FSH (157). We found similar levels, well within the normal range (F. H. De Jong and W. J. De Waal, unpublished results). On the other hand, the difference in 


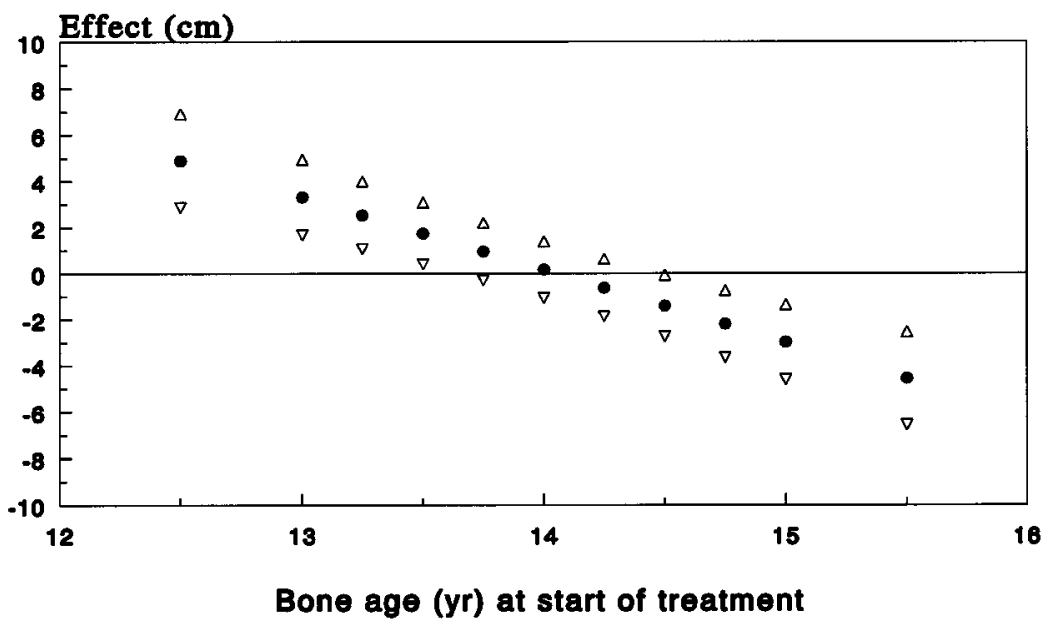

FIG. 1. Adjusted effect of androgen therapy. The effect of therapy was calculated by multiple regression analysis using final height as dependent variable and treatment, and $\mathrm{CA}, \mathrm{BA}$, and height prediction (and their interactions) as independent variables. Using the height prediction according to the index of potential height for bone age, the estimated treatment effect was a linear function related to BA (Greulich and Pyle) in the form: Effect $(\mathrm{cm})=44.19-3.15 \times \mathrm{BA}(\mathrm{yr})$. The solid dots $(-)$ represent all patients with a given bone age, and the open triangles $(\triangle)$ represent the $95 \%$ confidence interval of the calculated adjusted effect. [Reproduced with permission from W. J. de Waal et al.: J Clin Endocrinol Metab 81:1206-1216, 1996 (101). (C) The Endocrine Society.]

gonadotropin levels may also reflect a change in responsiveness at the hypothalamo-pituitary level (136).

2. Testicular volume. Treatment with high doses of androgens induces reduction in testicular volume in adult men (158) as well as in tall adolescent boys $(98,99,113)$. This implies major intratesticular changes during therapy such as a decrease in seminiferous tubule size $(149,150)$. These processes are likely to be reversible since testicular volume normalizes after discontinuation of therapy as shown in several studies $(98,99$, $113,158)$. This is in contrast to the observations of Willig et al. $(159,160)$, who reported significantly smaller testicular sizes in previously treated men. In contrast, in our studies at a mean follow-up period of $8 \mathrm{yr}$ after cessation of treatment, there was no difference in mean testicular volume between treated and untreated tall men (154).

3. Sperm quality. When sperm quality is evaluated, one must be aware of the normal distribution in the population as well as of confounding factors interfering with parameters of sperm quality. It is well established that varicocele (161-164), smoking (165), sexually transmitted disease (166), and cryptorchidism (167) are likely to affect sperm quality and/or plasma hormone levels. Semen analysis in our study of previously androgen-treated men showed that sperm quality was comparable with a control group of untreated tall men, even after correction for the above mentioned possible interfering conditions, after a mean follow-up period of $8 \mathrm{yr}$. These findings are in agreement with the experiences reported by Zachmann and Prader and co-workers $(98,113)$. In contrast, Willig and co-workers $(159,160)$ found significantly reduced sperm concentrations in previously treated tall men compared with controls. Their control group, however, showed a relative high mean value of sperm concentration of $120.2 \times 10^{\prime} 6 / \mathrm{ml}$, almost twice as high as values found in the normal population at present $(168,169)$. Their treated group showed a mean sperm concentration of $63.4 \times 10^{\prime} 6 /$ $\mathrm{ml}$, which is comparable with values found in our study (154). It is possible that differences in patient selection, semen analysis methodology, and treatment regimens may account for the observed differences. In addition, the extent to which interfering conditions are present may cause important bias as well. In a recent report Lemcke and co-workers (153) showed that $10 \mathrm{yr}$ after $\mathrm{T}$ treatment, none of the tall men had azoospermia, and the mean ejaculate parameters were in the normal range or only slightly subnormal. Overall, seminal parameters of T-treated tall men were slightly, but not significantly, lower compared with normal statured volunteers. Interestingly, they found a significantly higher prevalence of varicocele and maldescended testes in the tall men compared with their control group of normal volunteers (153). They surmised that varicocele and maldescended testes, rather than $\mathrm{T}$ treatment, caused the somewhat lower semen quality in the tall men. In our studies in treated and untreated tall men, we observed an overall prevalence of varicocele of $42 \%$ (12\% subclinical and 30\% clinical) (154). This would suggest that varicocele occurs more often than reported in the normal population (12.4-25.8\%) (170-172). A relationship to androgen treatment is unlikely since no difference in the prevalence of varicocele was observed between androgen-treated men and controls. One could speculate on the impact of stature on the pathogenesis of varicocele $(153,154)$.

4. Pregnancy/paternity. Thus far, only casuistic and exclusive female data have been available on successful pregnancies after height-reductive therapy. At the time of our follow-up studies five of the 43 androgen-treated men and six of the 30 untreated tall men had fathered one or more children (154). All 11 men reported that pregnancy had occurred in their partners after less than $1 \mathrm{yr}$ of unprotected coitus. Two other pregnancies, fathered by a previously treated man and a control, respectively, ended in spontaneous abortion. These very limited numbers do not allow any further conclusions. 


\section{Other clinical effects}

Many patients experience side effects during therapy (98, $99,113,132,173,174)$. Most of these, however, are mild and transient (see Table 7). In some patients, slight to moderate edema, notably in the pretibial or malleolar area, was associated with marked weight gain during the first 6 months of treatment. This indicates that the early gain in weight is not only due to protein anabolism but also to water retention (98). Acne was by far the most reported side effect $(98,99$, 175). Occasionally acne fulminans has been reported and necessitated discontinuation of therapy $(173,176)$. A causal relationship with androgen therapy is likely as shown by Fyrand et al. (177). Hinkel et al. (178) investigated the effects of high doses of androgens on lipoproteins during and after the cessation of therapy. Although during treatment a significant fall of triglycerides and HDL was observed, all values normalized after the end of treatment (178). In our studies, gynecomastia occurred in $13 \%$ of the cases. Since gynecomastia is rather prevalent in population studies in pubertal boys (179), it is difficult to say whether the condition had increased. One would expect that treatment would have effects on sexuality (sex interest, masturbation). Although in one study a marked increase of sexuality in younger, but not in older patients, was noted, it never exceeded the normal range seen in adolescence (98). Treatment with supraphysiological doses of $\mathrm{T}$ were not shown to provoke aggressive behavior in adolescents or young adults $(180,181)$.

\section{Estrogen Treatment in Tall Girls}

\section{A. Estrogen treatment modalities}

In 1956 Goldzieher introduced estrogen as a treatment of excessive growth in adolescent girls (182). Since then, many reports have appeared describing the height-reducing effect of high-dose estrogen therapy in tall girls $(64,101,103-109$, 112, 122-131). Many investigators, mainly in the United States, treated excessively tall girls with conjugated estrogens (114). In Western Europe, others used ethinyl estradiol (EE) in varying dosages usually combined with a progestogen 7-10 days each month to induce cyclic bleeding and to avoid overstimulation of the endometrium $(103,107,131)$. Norethisterone, medroxyprogesterone, and dydrogesterone have been used as progestagen, 5-10 mg/day. The two last

TABLE 7. Reported percentages of side effects during hormonal therapy in boys with CTS

\begin{tabular}{lccc}
\hline \multirow{2}{*}{\multicolumn{1}{c}{ Side effect }} & \multicolumn{3}{c}{ Reported percentage in study } \\
\cline { 2 - 4 } & $\begin{array}{l}\text { Brämswig } \\
\text { et al. (99) }\end{array}$ & $\begin{array}{c}\text { De Waal et al. } \\
(101)\end{array}$ & $\begin{array}{c}\text { Binder } \\
\text { et al. (181) }\end{array}$ \\
\hline Aggravation of acne & 64 & 39 & 28 \\
Painfulness of injection & 8 & 16 & \\
Weight gain & & 14 & \\
Gynecomastia & & 13 & 7 \\
Muscle ache & & 13 & 13 \\
Edema & 0 & 9 & \\
Change in psychological/sexual & & 5 & \\
$\quad$ behavior & & & \\
Hypertrichosis & 20 & & \\
Decreased performance after & & & \\
$\quad$ treatment & & & \\
\hline
\end{tabular}

preparations, in particular, show low to absent androgenic effects (183). In the past, estrogens have been administered in the form of stilbestrol, 1-5 mg per day $(112,113,182,184)$. However, since it has been reported to cause vaginal cancer in the female offspring of women treated during pregnancy $(185,186)$, stilbestrol is not a suitable treatment modality. It has the additional disadvantage of inducing marked pigmentation and hyperkeratosis of the nipple. Estradiol esters, such as estradiol-valerate and -benzoate, have been used since they were considered to be more 'physiological' than oral ethinyl estradiol (EE) or conjugated estrogens $(113,187)$. A disadvantage is that three injections per cycle are required. Considering all advantages and disadvantages, it appears that EE is the preparation of choice, since the dose is standardized, administration is easy, and side effects are not more marked or frequent than with any other preparation (103). Whether the estrogens are given continuously or cyclically seems to be of minor importance for the effect on height or for the resumption of regular menstrual cycles after discontinuation of treatment (103). It seems that the pituitary-gonadal axis tolerates continuous therapy for a period of 1-2 yr very well. In the 1960s most practitioners used 500 $\mu \mathrm{g} \mathrm{EE}$; in the 1970s 200-300 $\mu \mathrm{g}$ were used, and in the 19801990s a dosage of $100 \mu \mathrm{g} /$ day was claimed to be sufficient (101, 106, 107, 109, 113, 114, 125, 130, 131, 183, 188-191). Whether even lower dosages (e.g., $35 \mu \mathrm{g}$ daily) are equally effective remains to be assessed in a prospective clinical trial (131).

\section{B. Height reduction}

Studies on the effect of height reduction in tall girls have shown various results using different prediction models within the same study population (104, 105, 107-109, 124, $127,129)$. The mean calculated effect of therapy is 'corrected' by subtracting the systematic prediction error, as has been commonly reported in the literature. The mean reported height reduction ('corrected' and uncorrected) in girls with CTS ranged from 2.1 to $10 \mathrm{~cm}(64,101,103-109,112,122-131)$ (see Table 8). A clear comparison, however, is hampered by differences in initial clinical data (especially CA and BA), duration of treatment, therapeutic regimen (different doses and estrogen preparations), and the point in time of final height assessment. Concerning the latter, De Waal et al. (101) observed a mean (SD) additional growth of $2.7(1.1) \mathrm{cm}$ after cessation of therapy, which is of the same order of magnitude as in boys $(107,123,127)$. The cause of the observed additional growth is not quite clear. It could be explained by cessation of therapy before complete closure of the epiphyses. In addition, it is plausible that part of the remaining posttreatment growth reflects additional spinal growth.

As discussed earlier, evaluating the effect of sex steroid treatment after 'correction' for the mean errors of the separate prediction methods might induce bias. To calculate the 'net' treatment effect, multiple regression analysis has been used while adjusting for differences in age, BA, and height prediction between treated and untreated children. The mean adjusted effect for the various prediction methods varied from 1.1 to $2.4 \mathrm{~cm}$ and ranged from -2.6 to $6.2 \mathrm{~cm}$ in girls (101). These mean results are less than previously claimed 
TABLE 8. Effect of hormonal treatment in girls with CTS

\begin{tabular}{|c|c|c|c|c|c|c|c|c|c|}
\hline Study (Ref.) & $\mathrm{n}$ & Therapy & $\mathrm{CA}$ & G-P BA & $\begin{array}{l}\text { B-P Pred HT, } \\
\text { uncorrected }\end{array}$ & $\begin{array}{r}\text { Final HT } \\
\text { corrected }^{a}\end{array}$ & TW BA & $\begin{array}{l}\text { TW Pred HT, } \\
\text { uncorrected }\end{array}$ & $\begin{array}{l}\text { Final HT } \\
\text { corrected }^{a}\end{array}$ \\
\hline \multirow[t]{2}{*}{ Zachmann et al. (1975) (103) } & 40 & $\mathrm{EE}, 0.3 \mathrm{mg} /$ day & $12.9(1.2)$ & & & & $13.4(0.5)$ & $4.6(2.4)$ & 4.2 \\
\hline & 9 & Controls & $14.1(0.9)$ & & & & NR & $0.4(-)$ & \\
\hline Wettenhall et al. (1975) (112) & 87 & Stilbestrol $3 \mathrm{mg} /$ day & $13.0(1.1)$ & $13.2(0.8)$ & $3.5(2.2)$ & & & & \\
\hline $\begin{array}{l}\text { Von Puttkamer et al. (1977) } \\
\quad(122)\end{array}$ & 41 & $\begin{array}{l}\text { Conjugated estrogens, } \\
7.5 \mathrm{mg} / \text { day }\end{array}$ & $13.0(1.4)$ & $12.4(0.8)$ & $7.3(2.0)$ & & & & \\
\hline Kuhn et al. (1977) (123) & 17 & $\mathrm{EE}, 0.5 \mathrm{mg} /$ day & $12.7(1.2)$ & $12.6(0.6)$ & $6.2(2.8)$ & & & & \\
\hline \multirow{2}{*}{ Reeser et al. (1979) (104) } & 14 & $\mathrm{EE}, 0.2 \mathrm{mg} /$ day & $10.6(0.4)$ & $10.4(0.5)$ & $9.3(1.1)$ & 10.2 & NR & $7.1(1.4)$ & 7.0 \\
\hline & 14 & Controls & $10.7(0.3)$ & $11.2(0.4)$ & $-0.8(0.8)$ & & NR & $0.1(-)$ & \\
\hline \multirow[t]{2}{*}{ John and Schellong (1980) (105) } & 71 & $\mathrm{EE}, 0.3 \mathrm{mg} /$ day & $12.5(1.1)$ & $12.7(0.8)$ & $5.2(2.8)$ & 3.9 & $13.3(0.8)$ & $5.7(2.9)$ & 5.0 \\
\hline & 18 & Controls & $12.3(1.3)$ & 12.5 & $1.3(2.5)$ & & $13.4(1.3)$ & $0.7(2.5)$ & \\
\hline Andersen et al. (1980) (127) & 40 & $\begin{array}{l}\text { Estradiovalerate, } 30 \mathrm{mg} \\
\text { month im }\end{array}$ & $12.6(1.4)$ & $11.8(1.0)$ & $5.0(3.7)$ & & NR & $2.9(3.4)$ & \\
\hline $\begin{array}{l}\text { Stöver and Kollmann (1982) } \\
\text { (128) }\end{array}$ & 46 & $\begin{array}{l}\text { Conjugated estrogens, } \\
7.5 \mathrm{mg} / \text { day }\end{array}$ & $12.7(1.2)$ & NR & $5.8(3.2)$ & & $13.0(0.6)$ & $4.1(2.4)$ & \\
\hline \multirow[t]{2}{*}{ Sorgo et al. (1984) (129) } & 14 & $\begin{array}{l}\mathrm{EE}, 0.3 \mathrm{mg} / \text { day or } \\
\text { conjugated estrogens, } \\
7.5 \mathrm{mg} / \text { day }\end{array}$ & $12.0(1.4)$ & $11.8(1.4)$ & $6.5(5.5)$ & 4.2 & $12.7(1.0)$ & $5.5(5.5)$ & 2.1 \\
\hline & 7 & Controls & 13.5 & $13.1(1.1)$ & $2.3(3.6)$ & & $13.6(1.1)$ & $3.4(3.7)$ & \\
\hline \multirow[t]{5}{*}{$\begin{array}{l}\text { Schambach and Nitschke (1985) } \\
\text { (106) }\end{array}$} & 20 & $\begin{array}{l}\text { Mestrenol } 3 \times / \text { month } \\
80 \mu \mathrm{g} / \text { day }\end{array}$ & $9.8(0.7)$ & $9.3(0.4)$ & $7.6(1.7)$ & 8.1 & & & \\
\hline & 20 & Idem & $10.1(1.0)$ & $10.4(0.4)$ & $5.5(2.0)$ & & & & \\
\hline & 16 & Idem & $11.7(0.9)$ & $11.5(0.4)$ & $3.0(1.3)$ & & & & \\
\hline & 30 & Idem & $12.3(0.9)$ & $12.6(0.4)$ & $2.2(0.6)$ & & & & \\
\hline & 26 & Controls & $9.2(0.7)$ & $9.4(0.4)$ & $-0.5(2.5)$ & & & & \\
\hline \multirow{2}{*}{ Bartsch et al. (1988) (107) } & 35 & $\mathrm{EE}, 0.1 \mathrm{mg} /$ day & $12.3(-)$ & $12.5(-)$ & $4.2(2.3)$ & 3.9 & $13.1(-)$ & $4.0(-)$ & 3.6 \\
\hline & 23 & Controls & $12.5(-)$ & $12.5(-)$ & $0.6(2.2)$ & & NR & $0.4(-)$ & \\
\hline \multirow[t]{2}{*}{ Grüters et al. (1989) (130) } & 38 & $\mathrm{EE}, 0.5-0.3 \mathrm{mg} / \mathrm{day}$ & $12.5(1.6)$ & $12.4(0.8)$ & $4.9(2.6)$ & & & & \\
\hline & 44 & $\mathrm{EE}, 0.1 \mathrm{mg} /$ day & $12.4(1.4)$ & $12.4(0.8)$ & $5.1(2.4)$ & & & & \\
\hline \multirow{4}{*}{ Svan et al. (1991) (64) } & 21 & $\mathrm{EE}, 1.0 \mathrm{mg} /$ day & $13.4(1.5)$ & $12.9(0.8)$ & $5.5(2.7)$ & 4.3 & & & \\
\hline & 20 & $\mathrm{EE}, 0.5 \mathrm{mg} /$ day & $13.3(1.0)$ & $12.8(0.7)$ & $5.9(3.3)$ & 4.7 & & & \\
\hline & 15 & EE, $0.25 \mathrm{mg} /$ day & 13.5 & $12.6(0.9)$ & $5.6(2.7)$ & 4.4 & & & \\
\hline & 12 & Controls & NR & NR & $1.2(-)$ & & & & \\
\hline \multirow{3}{*}{ Normann et al. (1991) (131) } & 263 & $\mathrm{EE}, 0.5 \mathrm{mg} /$ day & $13.2(-)$ & $12.6(-)$ & $5.9(-)$ & & & & \\
\hline & 178 & EE, $0.25 \mathrm{mg} /$ day & $13.1(-)$ & $12.6(-)$ & $5.3(-)$ & & & & \\
\hline & 98 & $\mathrm{EE}, 0.1 \mathrm{mg} /$ day & $13.8(-)$ & $12.7(-)$ & $4.4(-)$ & & & & \\
\hline \multirow{4}{*}{ Joss et al. (1994) (109) } & 16 & $\mathrm{EE}, 0.5 \mathrm{mg} /$ day & $12.8(0.9)$ & NR & $6.9(1.6)$ & 4.5 & $12.5(0.3)$ & $5.1(2.7)$ & 3.8 \\
\hline & 25 & $\mathrm{EE}, 0.3 \mathrm{mg} /$ day & $12.8(0.9)$ & NR & $6.6(2.4)$ & 4.2 & $12.5(0.4)$ & $4.3(2.4)$ & 3.0 \\
\hline & 11 & $\mathrm{EE}, 0.1 \mathrm{mg} /$ day & $13.5(0.9)$ & NR & $6.5(2.1)$ & 4.1 & $12.5(0.3)$ & $3.6(2.1)$ & 2.6 \\
\hline & 21 & Controls & 13.0 & NR & $2.4(-)$ & & $12.6(1.1)$ & $1.3(2.8)$ & \\
\hline \multirow{2}{*}{ De Waal et al. (1996) (101) } & 159 & $\mathrm{EE}, 0.2 \mathrm{mg} /$ day & $12.7(1.2)$ & $12.4(1.0)$ & $4.1(3.0)$ & 3.6 & $13.3(1.1)$ & $1.4(3.3)$ & 2.2 \\
\hline & 88 & Controls & $12.8(1.5)$ & $12.9(1.4)$ & $0.5(2.7)$ & & 13.8 & $-0.8(3.1)$ & \\
\hline \multirow[t]{2}{*}{ Binder et al. (1997) (181) } & 56 & $\begin{array}{l}\text { Conjugated estrogens } \\
7.5 \mathrm{mg} / \text { day }\end{array}$ & $12.9(1.2)$ & $12.5(0.6)^{b}$ & $3.7(3.6)$ & 3.6 & & & \\
\hline & 79 & Controls & $11.8(1.5)$ & $12.3(1.4)$ & $0.1(3.6)$ & & & & \\
\hline
\end{tabular}

Data are expressed in centimeters as mean (SD). N, number; CA, chronological age at start of treatment; BA, bone age at start of treatment; EE, ethinyl estradiol; BP, Bayley-Pinneau (ref); TW1, Tanner-Whitehouse Mark 1 (80); TW2, Tanner-Whitehouse Mark 2 (80); TW-RUS, bone age RUS score according to method of Tanner-Whitehouse (80); BA-GP, bone age according to method of Greulich and Pyle (83); NR, not reported.

${ }^{a}$ Correction by subtraction of the mean prediction error of the control group.

${ }^{b}$ Bone age at start of study; bone age at start of treatment not given. 
FIG. 2. Adjusted effect of estrogen therapy. The effect of therapy was calculated by multiple regression analysis using final height as dependent variable and treatment, and CA, BA, height prediction, and menarche ( $0-$ no; 1 yes) (and their interactions) as independent variables. Using the Bayley-Pinneau prediction method, the estimated treatment effect was a linear function related to BA (Greulich and Pyle) in the form: effect $(\mathrm{cm}=20.22 \times 1.44 \times \mathrm{BA}$ (yr.). The solid dots (-) represent all patients with a given bone age and the open triangles $(\triangle)$ represent the $95 \%$ confidence interval of the calculated adjusted effect. [Reproduced with permission from W. J. de Waal et al.: J Clin Endocrinol Metab 81:1206-1216, 1996 (101). (C) The Endocrine Society.]

$(64,103-109,112,122-131)$, probably due to differences in statistical approach and study design, as explained above. Various studies show (as illustrated in Fig. 2) that the effect of treatment was more pronounced when treatment had been started at a younger BA $(105,108,112,123,130,131)$. However, others did not find such a relationship (103).

Results are inconsistent concerning whether or not premenarcheal girls may experience more height reduction compared with postmenarcheal girls. Some reports are in favor of this finding $(109,122,123,125)$ while others observed no difference $(103,107,128,130)$. In our study (101), premenarcheal girls seem to benefit more from therapy than postmenarcheal girls. However, this was likely to be due to the differences in CA between the groups since we found no additional effect of menarche on CA explaining the variability in the effect of treatment. This may, at least in part, explain the conflicting results.

\section{Effects on gonadal function}

1. The hypothalamo-pituitary-gonadal axis and menstrual cycles. Suppression of the hypothalamo-pituitary-gonadal axis induced by pharmacological doses of estrogens via a negative feedback mechanism was found to be reversible $(136,192)$. Hanker et al. (192) assessed the functional state of the hypothalamo-pituitary axis by standardized LHRH testing in 16 tall girls treated with $300 \mu \mathrm{g}$ EE daily for 7-26 months. While absent LH responses were observed in all girls immediately after therapy was stopped, 4 to 8 weeks later the LH responses had normalized in 13 girls and 12 weeks after therapy in 14 girls. All girls experienced spontaneous menstrual bleeding within 3 to 22 weeks after termination of therapy. The same was observed in most later follow-up studies in which first menstruation was reported within 1-6 months after cessation of treatment, in most cases even after the first month $(103,114,127,130)$. Amenorrhea of longer than 6 months after cessation of height-reductive therapy was reported in about $5 \%$ of the cases (175). The incidence of prolonged amenorrhea after cessation of oral anticonceptive therapy is about $0.5 \%$ (193). In addition, the overall prevalence of secondary amenorrhea of more than 6 months in women aged $15-34 \mathrm{yr}$ is about $1.3 \%$ (194). This may suggest an increase of amenorrhea after height-reductive therapy. It should be noted, however, that there are no convincing data that use of oral contraceptives (OCs) is causally related to amenorrhea and that other risk factors for amenorrhea, such as smoking, nutrition, and exercise, were not adequately investigated $(193,195)$. No differences were found in menstrual cycle characteristics between previously treated and untreated tall women after a mean follow-up period of almost 11 yr (175).

2. Pregnancy. In girls, pregnancy, which is the ultimate 'proof' of complete reversibility of hypothalamo-gonadal suppression, has been reported in various single cases $(112,113,127$, $128,130,131,189)$. In our own study, information on a total of 63 pregnancies was obtained from 40 previously treated tall women. No distinct differences in details and outcome of pregnancies between treated and untreated tall women were found (175). These results indicate that long-term effects of high doses of estrogens on fertility are unlikely.

Although a mean follow-up period of $10 \mathrm{yr}$ is still too short to draw definite conclusions, there is no clear evidence that treatment with high doses of sex steroids does induce harmful effects on reproductive function in tall girls.

\section{Other adverse effects}

In most studies, unwanted side effects have been reported only during treatment or shortly after discontinuation of therapy $(109,112,113,127,128,130,131,183,189,196,197)$. Most side effects were found to be mild and reversible (see Table 9). In a large retrospective study short-term and longterm effects of high doses of estrogens in the management of CTS were evaluated at a mean follow-up period of $10 \mathrm{yr}$ after discontinuation of height-reductive therapy. OCs were used by a high proportion of previously estrogen-treated girls as well as controls. An impressive bulk of data on the association between long-term OC use and possible health risks (reviewed in Refs. 198 and 199) form an excellent reflection of the prospective risk in estrogen-treated girls. The proportion of $O C^{\prime} s$ use and reported side effects were not significantly different between estrogen-treated and nontreated women. More than $70 \%$ of the estrogen-treated women had experienced one or more side effects during therapy, such as weight gain, headache, nausea, leg cramps at night, in- 
TABLE 9. Reported percentages of side effects during hormonal therapy in girls with CTS

\begin{tabular}{|c|c|c|c|c|}
\hline \multirow[b]{2}{*}{ Side effect } & \multicolumn{4}{|c|}{ Reported percentage in study } \\
\hline & $\begin{array}{c}\text { John and } \\
\text { Schellong (105) }\end{array}$ & $\begin{array}{c}\text { Trygstad } \\
\text { (183) }\end{array}$ & $\begin{array}{l}\text { De Waal } \\
\text { et al. }(101)\end{array}$ & $\begin{array}{c}\text { Binder } \\
\text { et al. }(181)\end{array}$ \\
\hline Headache/migraine & 14 & 2 & 13 & \\
\hline Nausea/vomitus & 27 & 66 & 14 & \\
\hline Fluor vaginalis & 10 & 2 & 13 & \\
\hline $\begin{array}{l}\text { Pigmentation of are- } \\
\text { ola and nipples }\end{array}$ & 38 & 23 & 27 & \\
\hline Weight gain & 44 & 90 & 41 & 13 \\
\hline Calf cramp & & $<1$ & 20 & 17 \\
\hline $\begin{array}{l}\text { Change in psycho- } \\
\text { logical/sexual be- } \\
\text { havior }\end{array}$ & & $<1$ & 3 & \\
\hline Galactorrhea & & 2 & 4 & \\
\hline Hypertrichosis & & $<1$ & 3 & \\
\hline Thrombosis & & & - & \\
\hline Hypertension & & & 2 & \\
\hline $\begin{array}{l}\text { Bleeding distur- } \\
\text { bances }\end{array}$ & 11 & 2 & 9 & \\
\hline $\begin{array}{l}\text { Cysts or tumors in } \\
\text { mammae/uterus } \\
\text { or ovariae }\end{array}$ & & $<1$ & 2 & \\
\hline Polyphagia & & $<1$ & 4 & \\
\hline Striae & 44 & & 3 & \\
\hline $\begin{array}{l}\text { Dizziness/orthostatic } \\
\text { problems }\end{array}$ & & & 1 & 7 \\
\hline
\end{tabular}

creased pigmentation of areola and nipples, and vaginal discharge. Although most of them were mild and transient, the adverse effects of estrogens occurred more frequently during therapy than during OC use (175). This would suggest a dose-dependent effect of estrogens on the incidence of adverse events $(107,130)$.

Although hemostatic changes have been reported (196, 200,201 ), thrombosis is found to be a very uncommon side effect of height-reductive therapy $(112,132,196)$. Whenever thrombosis occurred it usually coincided with other risk factors for thromboembolism such as immobilization (202). Galactorrhea is an infrequent side effect of estrogen therapy in tall girls $(113,123,183)$. Hyperprolactinemia may be more frequent but is reversible in most cases (Ref. 192 and M. C. A. M. Houdijk and H. A. Delemarre-Van de Waal, submitted for publication).

The effect of high-dose estrogens on lipid metabolism was evaluated in several studies $(178,204)$. The changes of serum lipids and lipoproteins during estrogen therapy were reversible after cessation of treatment.

Malignancy was not reported in our follow-up study (175). Although there have been no reported cases of ovarian, uterine, vaginal, or breast malignancies in girls treated for tall stature, the risk of cancer in young women receiving estrogens remains uncertain. The possibility of a dose-dependent effect and a relationship with OC use at a young age and duration of OC use with increased risks of breast cancer (205) point to the need for long-term follow-up of patients treated with pharmacological doses of estrogens.

\section{Alternative Treatment Modalities and Future Research}

An alternative strategy to limit growth in children with tall stature utilizes interference in the regulation of GH secretion.
It is based on the assumption that tall stature is related to GH hypersecretion. Bromocriptine therapy has been proposed as a means to suppress endogenous GH secretion. Bromocriptine is a dopamine agonist and inhibits GH secretion in patients with acromegaly by binding to pituitary dopamine receptors (206). In the 1980s, studies on the effectiveness of bromocriptine in reducing final adult height in children with CTS revealed conflicting results. The studies of Evain-Brion and colleagues (207-210) reported marked decreases in height prediction in a group of about 30 adolescents after a treatment period of 9-15 months. It was stated that the reductive effect on height prediction was mainly due to an increase in bone maturation rather than a decrease in height velocity; IGF-I and IGF-II levels remained unchanged. In contrast, other studies did not substantiate the effect of bromocriptine treatment on height prediction or skeletal maturation in children with tall stature (211-213). Recently, research has focused on somatostatin analogs for the management of tall stature. Somatostatin is a neurohormone produced at the hypothalamic level that has potent inhibitory properties on $\mathrm{GH}$ release in the pituitary via the vascular network of the portal system (214). Preliminary data revealed an effective suppression of GH secretion in small groups of tall children and a significant reduction in growth rate and predicted adult height (215-218). In addition, plasma IGF-I levels decreased whereas bone maturation accelerated in many of the treated children (216). The effect of somatostatin on bone maturation suggests that somatostatin acts not only by systemic hormonal effects on GH and / or IGFs but also by local regulatory effects on bone growth and metabolism. This hypothesis is supported by the observation of Lamberts (219), who found symmetrical bands of increased radioactivity by means of in vivo somatostatin receptor-imaging techniques at the epiphyseal surfaces of children with neuroblastoma. Final results on height reduction by somatostatin therapy have not yet been established, and the possibility of serious side effects such as gall stones must be considered.

Strategies to limit final height of tall children have centered around the peripubertal years. This is mainly due to the use of high doses of sex steroids to advance skeletal maturation. Hindmarsh et al. (218) suggested that in the management of children with tall stature, attempts should be made to reduce the prepubertal contribution to stature. Since prepubertal growth is largely GH dependent, somatostatin analogs might be used to reduce the actual height from which the pubertal growth spurt will commence. In addition, sex steroid therapy may be applied as an adjuvant during puberty to optimize the ultimate height-reducing effect. Other possibilities are low-dose sex steroid treatment starting at an early prepubertal age (106), or orthopedic modalities such as bilateral epiphysiodesis around the knee (220) or femoral shortening (221).

\section{Conclusions and Recommendations}

Treatment of CTS is generally based on psychological grounds. Children and adults with excessive growth may suffer considerably from being much taller than their peers. Although psychosocial factors form the main reason for 
treatment, extensive psychological investigation before or during height-reductive therapy has never been performed. There are no objective prospective data indicating lifelong psychosocial damage as a result of tallness. In two retrospective studies men and women previously treated with high doses of sex steroids because of CTS showed no major psychological maladjustment compared with tall controls $(180,181)$. Nevertheless, many tall individuals experience practical problems concerning clothing and shoes, are teased, and are subject to hurtful remarks and jokes about their height. Thus, careful attention should be paid to the psychosocial problems related to tallness especially in relation to the sociocultural environment when considering treatment.

Prospective controlled studies that answer the main question of whether treatment with pharmacological doses of sex steroids is effective in reducing final height have never been performed. As claimed effectiveness is based on height prediction, a critical appraisal of the quality of the various prediction methods is in order. Height prediction in tall girls is more accurate than in boys.

It is suggested that height prognosis in children with excessive growth is more accurate when based on growth data derived from untreated tall children (101). It must be emphasized that although prediction techniques may have small mean errors of prediction, in individual cases considerable errors in height prognosis may be made. This is reflected by the presence of the relatively large sDs of the mean errors of the prediction method applied (191). It is preferable, therefore, to give predicted adult height as a height with a confidence limit using the residual SDs of the prediction technique for calculation (see Table 5). Repeated measurements at intervals of 4-6 months will improve the clinical relevance of the prediction. Treatment with supraphysiological doses of sex steroids has been advocated for final height reduction since 1950 .

When the many reports in the literature on the heightlimiting effect of sex steroid treatment are analyzed, one may conclude that height reduction is dependent on the BA at the time of start of treatment. In our experience, tall girls benefit more from sex steroid therapy than tall boys, but data from the literature are not consistent.

As shown in Figs. 1 and 2, the period during which effective height reduction is to be expected is quite limited. The upper limit of this period is determined by BA (Greulich and Pyle) of $<14$ yr in boys and of $<13.5-14$ yr in girls. The lower limit is determined by psychosocial constraints, as treatment clearly induces puberty. Posttreatment growth caused by cessation of treatment before complete closure of the epiphyses may cause a significant reduction of the height-limiting effect of treatment. The optimal dose of sex steroids is not known. In the course of time the dosage of oral ethinyl estradiol for girls has been reduced gradually from $500 \mu \mathrm{g} /$ day to 100-200 $\mu \mathrm{g} /$ day. In boys, long-acting T esters, 1000 $\mathrm{mg} / \mathrm{m}^{2} /$ month, is most often recommended administered ip once per 1 or $2 \mathrm{wk}$. For late maturing individuals, it is advisable to initially prescribe a reduced dose with subsequent gradual increments.

To date, no evidence of long-term side effects of high doses of sex steroids have been demonstrated after 8-10 yr. This limits the need for a prospective trial to assess the effective- ness of a lower dosage regimen. On the other hand, in view of a relationship with OC use at a young age and duration of OC use with increased risks of breast cancer (205), there is a need for long-term follow-up of individuals treated with pharmacological doses of estrogens. Similarly, while no hard evidence of testicular damage has been established after androgen treatment in tall boys, the finding in one study of marginally elevated FSH levels along with normal sperm counts, testicular volume, and endocrinological parameters including inhibin B levels, warrants further study.

In conclusion, it is recommended first to refer constitutionally tall children in the late prepubertal period ( $8-10 \mathrm{yr})$ to secure proper pretreatment evaluation of growth and bone maturation. Second, to restrict treatment to excessive tallness or a very outspoken professional desire where height forms a clear limitation (e.g., pilot, ballet dancer). Third, treatment should be initiated at an early 'bone age,' psychosocial constraints permitting. Treatment should not start before an age corresponding to the 10th percentile of the first stage of pubertal development. Moreover, although retrospective studies have not provided hard evidence of testicular damage, it should be realized that in boys androgen treatment might interfere with pubertal testicular development. Finally, treatment should be continued until complete closure of the epiphyses has been established radiologically.

In view of the crucial role of $\mathrm{GH}$ during the pubertal growth spurt, it is tempting to speculate on other treatment modalities that might be as effective or perhaps even more effective than the current practice. There may be new ways of effectively suppressing GH secretion not only by somatostatin analogs (223), but also by GHRH or GH antagonists (224-226).

\section{Acknowledgments}

The authors thank Mrs. A. Oudesluys-Murphy for a careful linguistic review of the manuscript and gratefully acknowledge the expert bibliothecarial assistance of Mrs. M. L. van Rooijen-Dekkers and the secretarial assistance of Mrs. A. Visser-Vermeer.

\section{References}

1. Tanner JM 1962 Growth at Adolescence, ed 2. Blackwell Scientific Publications, Oxford, U.K.

2. Mascie-Taylor CG 1991 Biosocial influences on stature: a review. J Biosoc Sci 23:113-128

3. Sorva R, Tolppanen EM, Lankinen S, Perheentupa J 1989 Growth evaluation: parent and child specific height standards. Arch Dis Child 64:1483-1487

4. Garralda MD 1992 Evolution of human height. In: Hernandez M, Argente J (eds) Human Growth. Excerpta Medica, Amsterdam, pp 135-142

5. Styne DM, McHenry H 1993 The evolution of stature in humans. Horm Res 39 [Suppl 3]:3-6

6. Eveleth PB, Tanner JM 1990 Worldwide Variation in Human Growth, ed 2. Cambridge University Press, Cambridge, U.K.

7. Roede MJ, Van Wieringen JC 1985 Growth diagrams 1980. Netherlands third nation-wide survey. Tijdschr Soc Gezondheidszorg 63[Suppl]:1-34

8. Reinken L, Van Oost G 1992 Longitudinale Körperentwicklung gesunder Kinder von 0 bis 18 Jahren: Körperlange/-höhe, Körpergewicht und Wachstumsgeschwindigkeit. Klin Pädiatr 204:129-133

9. Karlberg P, Taranger J, Engström I, Karlberg J, Landström T, 
Lichtenstein H, Lindström B, Svennberg-Redegren I 1976 Physical growth from birth to 16 years and longitudinal outcome of the study during the same age period. Acta Paediatr Scand Suppl 258:7-76

10. Anonymous 1993 Celostátni antropologicky vyzkum deti a mládeze v rece 1991 (Ceské zeme): Vybrané antropmetrické charakteristsiky. Cs Pediatr 48:621-630

11. Andersen E, Hutchings B, Jansen J, Nyholm M 1982 Højde og vaegt hos danske børn. Ugeskr Laeger 144:1760-1765

12. Freeman JV, Cole TJ, Chinn S, Jones PRM, White EM, Preece MA 1995 Cross sectional stature and weight reference curves for the UK, 1990. Arch Dis Child 73:17-24

13. Hamill PV, Drizd TA, Johnson CL, Reed RB, Roche AF 1977 NCHS growth curves for children birth-18 years. United States. Vital Health Stat [11] (165):i-iv, 1-74

14. Sempé M, Pédron G, Roy P 1979 Auxologie, Méthode et Séquences. Théraplix, Paris

15. Galvan R 1975 Somatometria pediatrica estudio semilongitudinal en niños de ciudad de méxico. Arch Invest Med 6[Suppl 1]

16. Neyzi O, Binyildiz P, Alp H 1978 Türk çocuklarinin persentil büyüme egrileri (0-17 yas). Ist Tip Fak Mecm 41 [Suppl 74]

17. Lejarrage H, Orfila G 1987 Estandares de peso y estatura para niñas y niños argentinos desde el nacimiento hasta la madurez. Arch Argent Pediatr 85:209-222

18. Heun HY, Park SY 1979 A study on physical growth and development and nutritional status of primary, middle and high school students in an urban area. Korean J New Med 22:55-62

19. Dickerman Z, Loewinger J, Laron Z 1984 The pattern of growth in children with constitutional tall stature from birth to age 9 years: a longitudinal study. Acta Paediatr Scand 73:530-536

20. Albertsson-Wikland K, Rosberg S 1988 Analyses of 24-hour growth hormone profiles in children: relation to growth. J Clin Endocrinol Metab 67:493-500

21. Rochiccioli P, Messina A, Tauber MT, Enjaume C 1989 Correlation of the parameters of 24-hour growth hormone secretion with growth velocity in 93 children of varying height. Horm Res 31: $115-118$

22. Brook CGD, Hindmarsh PC 1992 The somatotropic axis in puberty. Endocrinol Metab Clin North Am 21:767-782

23. Juul A, Bang P, Hertel NT, Main K, Dalgaard P, Jørgensen K, Müller J, Hall K, Skakkebaek NE 1994 Serum insulin-like growth factor-I in 1030 healthy children, adolescents, and adults: relation to age, sex, stage of puberty, testicular size, and body mass index. J Clin Endocrinol Metab 78:744-752

24. Gourmelen M, Le Bouc Y, Girard F, Binoux M 1984 Serum levels of insulin-like growth factor (IGF) and IGF binding protein in constitutionally tall children and adolescents. J Clin Endocrinol Metab 59:1197-1203

25. Albertsson-Wikland K, Rosberg S, Karlberg J, Groth T 1994 Analysis of 24-hour growth hormone profiles in healthy boys and girls of normal stature: relation to puberty. J Clin Endocrinol Metab 78:1195-1201

26. Rosenfield RI, Furlanetto R, Bock D 1983 Relationship of somatomedin-C concentrations to pubertal changes. J Pediatr 103:723-728

27. Zachmann M, Prader A, Sobel EH, Crigler Jr JF, Ritzén EM, Atarés M, Ferrandez A 1986 Pubertal growth in patients with androgen insensitivity: indirect evidence for the importance of estrogens in pubertal growth of girls. J Pediatr 108:694-697

28. Eakman GD, Dallas JS, Ponder SW, Keenan BS 1996 The effects of testosterone and dihydrotestosterone on hypothalamic regulation of growth hormone secretion. J Clin Endocrinol Metab 81: 1217-1223

29. Garcia Blanco M, Evain Brion D 1984 Studies in constitutionally tall adolescents: somatostatin decrease associated with growth hormone increase after TRH injection. Clin Endocrinol (Oxf) 21:459463

30. Batrinos M, Georgiadis E, Panitsa-Faflia C, Stratigopoulos S 1989 Increased GH response to GHRH in normal tall men. Clin Endocrinol (Oxf) 30:13-17

31. Evain-Brion D, Garnier P, Schimpff RM, Chaussain JL, Job JC 1983 Growth hormone response to thyrotropin-releasing hormone and oral glucose-loading tests in tall children and adolescents. J Clin Endocrinol Metab 56:429-432
32. Tauber M, Pienkowski C, Rochiccioli P 1994 Growth hormone secretion in children and adolescents with familial tall stature. Eur J Pediatr 153:311-316

33. Hindmarsh PC, Stanhope R, Kendall BE, Brook CG 1986 Tall stature: a clinical, endocrinological and radiological study. Clin Endocrinol (Oxf) 25:223-231

34. Turner RT, Riggs BL, Spelsberg TC 1994 Skeletal effects of estrogen. Endocr Rev 15:275-300

35. Turner RT, Evans GL, Wakley GK 1994 Reduced chondroclast differentiation results in increased cancellous bone volume in estrogen-treated growing rats. Endocrinology 134:461-466

36. Ohlsson C, Isgaard J, Törnell J, Nilsson A, Isaksson OGP, Lindahl A 1993 Endocrine regulation of longitudinal bone growth. Acta Paediatr Suppl 391:33-40

37. Robinson ICAF, Carmignac DF, Fairhall KM 1993 Growth hormone $(\mathrm{GH})$ receptors, $\mathrm{GH}$ binding protein and $\mathrm{GH}$ : an autoregulatory system? Acta Paediatr Suppl 391:22-28

38. Green H, Morikawa M, Nixon T 1985 A dual effector theory of growth-hormone action. Differentiation 29:195-198

39. Ohlsson C, Nilsson A, Isaksson O, Lindahl A 1992 Growth hormone induces multiplication of the slowly cycling germinal cells of the rat tibial growth plate. Proc Natl Acad Sci USA 89:9826-9830

40. Zapf J, Hunziker EB 1994 The somatomedin hypothesis revisited: differential effects of growth hormone and IGF-I on skeletal growth of the rat in vivo. In: Baxter RC, Gluckman PD, Rosenfeld RG (eds) The Insulin-like Growth Factors and Their Regulatory Proteins. Excerpta Medica International Congress series, 1056. Elsevier, Amsterdam, pp 381-391

41. Spagnoli A, Rosenfeld RG 1996 The mechanisms by which growth hormone brings about growth: the relative contributions of growth hormone and insulin-like growth factors. Endocrinol Metab Clin North Am 25:615-631

42. Giustina A, Wehrenberg WB 1995 Influence of thyroid hormones on the regulation of growth hormone secretion. Eur J Endocrinol 133:646-653

43. Ohlsson C, Nilsson A, Isaksson O, Bentham J, Lindahl A 1992 Effects of tri-iodothyronine and insulin-like growth factor-I (IGF-I) on alkaline phosphatase activity, $\left[{ }^{3} \mathrm{H}\right]$ thymidine incorporation and IGF-I receptor mRNA in cultured rat epiphyseal chondrocytes. J Endocrinol 135:115-123

44. Weiss RE, Refetoff S 1996 Effect of thyroid hormone on growth: lessons from the syndrome of resistance to thyroid hormone. Endocrinol Metab Clin North Am 25:719-730

45. Klaus G, Merke J, Eing H, Hügel U, Milde P, Reichel H, Ritz E, Mehls O 1991 1,25(OH)2D3 receptor regulation and 1,25(OH)2D3 effects in primary cultures of growth cartilage cells of the rat. Calcif Tissue Int 49:340-348

46. Econs MJ, Drezner MK 1992 Bone disease resulting from inherited disorders of renal tubule transport and vitamin D metabolism. In: Coe FL, Favus MJ (eds) Disorders of Bone and Mineral Metabolism. Raven Press, New York, pp 935-950

47. Mohan S, Baylink DJ 1993 Characterization of the IGF regulatory system in bone. Adv Exp Med Biol 343:397-406

48. Frank GR 1995 The role of estrogen in pubertal skeletal physiology: epiphyseal maturation and mineralization of the skeleton. Acta Paediatr 84:627-630

49. Caruso-Nicoletti M, Cassorla F, Skerda M, Ross JL, Loriaux DL, Cutler Jr GB 1985 Short term, low dose estradiol accelerates ulnar growth in boys. J Clin Endocrinol Metab 61:896-898

50. Klein KO, Baron J, Colli MJ, McDonnell DP, Cutler Jr GB 1994 Estrogen levels in childhood determined by an ultrasensitive recombinant cell bioassay. J Clin Invest 94:2475-2480

51. Marin G, Domené HM, Barnes KM, Blackwell BJ, Cassorla FG, Cutler Jr GB 1994 The effects of estrogen priming and puberty on the growth hormone response to standardized treadmill exercise and arginine-insulin in normal girls and boys. J Clin Endocrinol Metab 79:537-541

52. Klein KO, Martha Jr PM, Blizzard RM, Herbst T, Rogol AD 1996 A longitudinal assessment of hormonal and physical alterations during normal puberty in boys II: estrogen levels as determined by ultrasensitive bioassay. J Clin Endocrinol Metab 81:3203-3207

53. Ross JL, Long LM, Skerda M, Cassorla F, Kurtz D, Loriaux DL, Cutler Jr GB 1986 Effect of low doses of estradiol on 6-month 
growth rates and predicted height in patients with Turner syndrome. J Pediatr 109:950-953

54. Ranke MB, Haug F, Blum WF, Rosendahl W, Attanasio A, Bierich JR 1986 Effect on growth of patients with Turner's syndrome treated with low estrogen doses. Acta Endocrinol Suppl (Copenh) 279:153-156

55. Vanderschueren-Lodeweyckx M, Massa G, Maes M, Craen M, Van Vliet G, Heinrichs C, Malvaux P 1990 Growth-promoting effect of growth hormone and low dose ethinyl estradiol in girls with Turner's syndrome. J Clin Endocrinol Metab 70:122-126

56. Oostdijk W, Rikken B, Schreuder S, Otten B, Odink R, Rouwé C, Jansen M, Gerver WJ, Waelkens J, Drop S 1996 Final height in central precocious puberty after long term treatment with a slow release GnRH agonist. Arch Dis Child 75:292-297

57. Ritzén EM 1992 Pubertal growth in genetic disorders of sex hormone action and secretion. Acta Paediatr Suppl 383:22-25

58. Laue L, Kenigsberg D, Pescovitz OH, Hench KD, Barnes KM, Loriaux DL, Cutler Jr GB 1989 Treatment of familial male precocious puberty with spironolactone and testolactone. N Engl J Med 320:496-502

59. Foster CM, Hopwood NJ, Hassing JM, Hale PM, Mendes T, Kelch RP, Beitins IZ 1989 Nocturnal serum growth hormone concentration is not augmented by short-term testosterone infusion in pubertal boys. Pediatr Res 26:320-324

60. Cemeroglu AP, Barkan AL, Kletter GB, Beitins IZ, Foster CM 1997 Changes in serum immunoreactive and bioactive growth hormone concentrations in boys with advancing puberty and in response to a 20-hour estradiol infusion. J Clin Endocrinol Metab 82:2166-2171

61. Van Den Bosch JSG, Smals AGH, Kloppenborg PWC, Valk IM 1981 The effect of low dose oestrogens on short-term growth and concomitant biochemical phenomena in girls with tall stature. Acta Endocrinol (Copenh) 98:156-160

62. Van Den Bosch JSG, Smals AGH, Pieters GFFM, Valk IM, Kloppenborg PWC 1982 Instant growth inhibition by low dose oestrogens in excessively tall boys. Acta Endocrinol (Copenh) 100:327332

63. Clemmons DR, Underwood LE, Ridgway EC, Kliman B, Kjellberg RN, Van Wyk JJ 1980 Estradiol treatment of acromegaly: reduction of immunoreactive somatomedin-C and improvement in metabolic status. Am J Med 69:571-575

64. Svan H, Ritzén EM, Hall K, Johansson L 1991 Estrogen treatment of tall girls: dose dependency of effects on subsequent growth and IGF-I levels in blood. Acta Paediatr Scand 80:328-332

65. Smith EP, Boyd J, Frank GR, Takahashi H, Cohen RM, Specker B, Williams TC, Lubahn DB, Korach KS 1994 Estrogen resistance caused by a mutation in the estrogen-receptor gene in a man. N Engl J Med 331:1056-1061

66. Conte FA, Grumbach MM, Ito Y, Fisher CR, Simpson ER 1994 A syndrome of female pseudohermaphrodism, hypergonadotropic hypogonadism, and multicystic ovaries associated with missense mutations in the gene encoding aromatase (P450arom). J Clin Endocrinol Metab 78:1287-1292

67. Malhotra A, Poon E, Tse WY, Pringle PJ, Hindmarsh PC, Brook CGD 1993 The effects of oxandrolone on the growth hormone and gonadal axes in boys with constitutional delay of growth and puberty. Clin Endocrinol (Oxf) 38:393-398

68. Keenan BS, Richards GE, Ponder SW, Dallas JS, Nagamani M, Smith ER 1993 Androgen-stimulated pubertal growth: the effects of testosterone and dihydrotestosterone on growth hormone and insulin-like growth factor-I in the treatment of short stature and delayed puberty. J Clin Endocrinol Metab 76:996-1001

69. Blanchard O, Tsagris L, Rappaport R, Duval-Beaupere G, Corvol M 1991 Age-dependent responsiveness of rabbit and human cartilage cells to sex steroids in vitro. J Steroid Biochem Mol Biol 40:711-716

70. Nasatzky E, Schwartz Z, Boyan BD, Soskolne WA, Ornoy A 1993 Sex-dependent effects of 17-beta-estradiol on chondrocyte differentiation in culture. J Cell Physiol 154:359-367

71. Schwartz Z, Nasatzky E, Ornoy A, Brooks BP, Soskolne WA, Boyan BD 1994 Gender-specific, maturation-dependent effects of testosterone on chondrocytes in culture. Endocrinology 134:16401647

72. Gustafsson PO, Kasstrom H, Lindberg L, Olsson SE 1975 Growth and mitotic rate of the proximal tibial epiphyseal plate in hypophysectomized rats given estradiol and human growth hormone. Acta Radiol Suppl 344:69-74

73. Breur GJ, VanEnkevort BA, Farnum CE, Wilsman NJ 1991 Linear relationship between the volume of hypertrophic chondrocytes and the rate of longitudinal bone growth in growth plates. J Orthop Res 9:348-359

74. Thorngren KG, Hansson LI 1973 Cell kinetics and morphology of the growth plate in the normal and hypophysectomized rat. Calcif Tissue Res 13:113-129

75. Whitson SW, Dawson LR, Jee WSS 1978 A tetracycline study of cyclic longitudinal bone growth in the female rat. Endocrinology 103:2006-2010

76. Strickland AL, Sprinz H 1973 Studies of the influence of estradiol and growth hormone on the hypophysectomized immature rat epiphyseal cartilage growth plate. Am J Obstet Gynecol 115:471477

77. Saggese G, Federico G, Cinquanta L 1993 In vitro effects of growth hormone and other hormones on chondrocytes and osteoblast-like cells. Acta Paediatr Suppl 391:54-59

78. McCarthy TL, Ji C, Shu H, Casinghino S, Crothers K, Rotwein P, Centrella M $199717 \beta$-Estradiol potently suppresses cAMPinduced insulin-like growth factor-I gene activation in primary rat osteoblast cultures. J Biol Chem 272:18132-18139

79. Tanner JM, Whitehouse RH, Marshall WA, Carter BS 1975 Prediction of adult height from height, bone age, and occurrence of menarche, at ages 4 to 16 with allowance for midparent height. Arch Dis Child 50:14-26

80. Tanner JM, Whitehouse RH, Cameron N, Marshall W, Healy MJR, Goldstein H 1983 Assessment of Skeletal Maturity and Prediction of Adult Height (TW2 Method), ed 2. Academic Press, London

81. Bayley N, Pinneau S 1952 Tables for predicting adult height from skeletal age: revised for use with the Greulich-Pyle hand standards. J Pediatr 40:423-441

82. Cameron N 1995 The prediction of adult height. In: Hauspie R, Lindgren G, Falkner F (eds) Essays on Auxology: Presented to James Mourilyan Tanner by Former Colleagues and Fellows. Castlemead Publications, Welwyn Garden City, U.K., pp 126-140

83. Greulich WW, Pyle SI 1959 Radiographic Atlas of Skeletal Development of the Hand and Wrist, ed 2. Stanford University Press, Stanford, CA

84. Preece MA 1988 Prediction of adult height: methods and problems. Acta Paediatr Scand Suppl 347:4-11

85. Roche AF, Chumlea WC, Thissen D 1988 The Skeletal Maturity of the Hand and Wrist: the FELS Method. Charles C Thomas, Springfield, IL

86. Roche AF, Davila GH, Eyman SL 1971 A comparison between Greulich-Pyle and Tanner-Whitehouse assessments of skeletal maturity. Radiology 98:273-280

87. Kemperdick HF 1981 Skelettalter-Bestimmung bei Kindern mit normalem und abweichendem Wachstumsverlauf. Fortschr Med 99:152-156

88. King DG, Steventon DM, O'Sullivan MP, Cook AM, Hornsby VPL, Jefferson IG, King PR 1994 Reproducibility of bone ages when performed by radiology registrars: an audit of Tanner and Whitehouse II vs. Greulich and Pyle methods. Br J Radiol 67:848851

89. Zachmann M, Sobradillo B, Frank M, Frisch H, Prader A 1978 Bayley-Pinneau, Roche-Wainer-Thissen, and Tanner height predictions in normal children and in patients with various pathologic conditions. J Pediatr 93:749-755

90. Benso L, Vannelli S, Pastorin L, Angius P, Milani S 1996 Main problems associated with bone age and maturity evaluation. Horm Res 45[Suppl 2]:42-48

91. Gilli G 1996 The assessment of skeletal maturation. Horm Res 45[Suppl 2]:49-52

92. Cox LA 1996 Tanner-Whitehouse method of assessing skeletal maturity: problems and common errors. Horm Res 45[Suppl 2]:53-55

93. Tanner JM, Gibbons RD 1994 Automatic bone age measurement using computerized image analysis. J Pediatr Endocrinol 7:141-145

94. Tanner JM, Gibbons RD 1994 A computerized image analysis 
system for estimating Tanner-Whitehouse 2 bone age. Horm Res 42:282-287

95. Van Teunenbroek A, De Waal W, Roks A, Chinafo P, Fokker M, Mulder P, De Muinck Keizer-Schrama S, Drop S 1996 Computeraided skeletal age scores in healthy children, girls with Turner syndrome, and in children with constitutionally tall stature. Pediatr Res 39:360-367

96. Drayer NM, Cox LA 1994 Assessment of bone ages by the TannerWhitehouse method using a computer-aided system. Acta Paediatr Suppl 406:77-80

97. Gibbons RD, Patterson D 1995 Application of computerized image analysis to estimating bone age. In: Hauspie R, Lindgren G, Falkner F (eds) Essays on Auxology: Presented to James Mourilyan Tanner by Former Colleagues and Fellows. Castlemead Publications, Welwyn Garden City, U.K., pp 106-118

98. Zachmann M, Ferrandez A, Mürset G, Gnehm HE, Prader A 1976 Testosterone treatment of excessively tall boys. J Pediatr 88:116-123

99. Brämswig JH, Schellong G, Borger HJ, Breu H 1981 TestosteronTherapie hochwüchsiger Jungen: Ergebnisse bei 25 Jungen. Dtsch Med Wochenschr 106:1656-1661

100. Brämswig JH, Hermeling W, Von Petrykowski W, Schellong G 1984 Comparison of height predictions with final adult height in boys with constitutional tall stature. In: Borms J, Hauspie R, Sand A, Susanne C, Hebbelinck M (eds) Human Growth and Development. Plenum Press, New York, pp 423-429

101. De Waal WJ, Greyn-Fokker MH, Stijnen T, Van Gurp EA, Toolens AM, De Muinck Keizer-Schrama SMPF, Aarsen RSR, Drop SLS 1996 Accuracy of final height prediction and effect of growth-reductive therapy in 362 constitutionally tall children. J Clin Endocrinol Metab 81:1206-1216

102. Joss EE, Temperli R, Mullis PE 1992 Adult height in constitutionally tall stature: accuracy of five different height prediction methods. Arch Dis Child 67:1357-1362

103. Zachmann M, Ferrandez A, Mürset G, Prader A 1975 Estrogen treatment of excessively tall girls. Helv Paediatr Acta 30:11-30

104. Reeser HM, Heremans GFP, Van Gelderen HH 1979 Reduction of adult height in tall girls. Eur J Pediatr 132:37-41

105. John G, Schellong G 1980 Östrogentherapie hochwüchsiger Mädchen: Ergebnisse bei 71 Patientinnen. Monatsschr Kinderheilkd 128:545-550

106. Schambach H, Nitschke U 1985 Die Behandlung des konstitutionellen Hochwuchses bei Mädchen mit physiologischen Östrogendosen in der Präpubertät: Eine Alternative zur hochdosierten Östrogentherapie. Monatsschr Kinderheilkd 133:32-37

107. Bartsch O, Weschke B, Weber B 1988 Oestrogen treatment of constitutionally tall girls with $0.1 \mathrm{mg} /$ day ethinyl oestradiol. Eur J Pediatr 147:59-63

108. Ignatius A, Lenko HL, Perheentupa J 1991 Oestrogen treatment of tall girls: effect decreases with age. Acta Paediatr Scand 80:712-717

109. Joss EE, Zeuner J, Zurbrügg RP, Mullis PE 1994 Impact of different doses of ethinyl oestradiol on reduction of final height in constitutionally tall girls. Eur J Pediatr 153:797-801

110. Cameron N, Mirwald RL, Bailey DA, Davies PSW 1985 The application of new height-prediction equations (Tanner-Whitehouse mark 2) to a sample of Canadian boys. Ann Hum Biol 12:233-239

111. De Waal WJ, Stijnen T, Lucas IS, Van Gurp EAFJ, De Muinck Keizer-Schrama SMPF, Drop SLS 1996 A new model to predict final height in constitutionally tall children. Acta Paediatr 85:889893

112. Wettenhall HNB, Cahill C, Roche AF 1975 Tall girls: a survey of 15 years of management and treatment. J Pediatr 86:602-610

113. Prader A, Zachmann M 1978 Treatment of excessively tall girls and boys with sex hormones. Pediatrics 62:1202-1210

114. Bailey JD, Park E, Cowell C 1981 Estrogen treatment of girls with constitutional tall stature. Pediatr Clin North Am 28:501-512

115. Zachmann M 1989 Use and risks of androgen therapy: replacement, constitutional delay, and tall stature. In: Forest MG (ed) Androgens in Childhood: Biological, Physiological, Clinical and Therapeutic Aspects. Pediatric and Adolescent Endocrinology. Karger, Basel, vol 19:247-263

116. Hazebroek-Kampschreur AAJM, Hofman A, Van Dijk AP, Van Linge B 1994 Determinants of trunk abnormalities in adolescence. Int J Epidemiol 23:1242-1247
117. Hazebroek-Kampschreur AAJM, Hofman A, Van Dijk AP, Van Linge B 1995 Two year cumulative incidence of trunk abnormalities in a school population in Rotterdam, The Netherlands. Eur J Public Health 5:220-222

118. Schoevaart CE, Drop SLS, Otten BJ, Slijper FME, Degenhart HJ 1990 Growth analysis up to final height and psychosocial adjustment of treated and untreated patients with precocious puberty. Horm Res 34:197-203

119. Brauner R, Adan L, Malandry F, Zantleifer D 1994 Adult height in girls with idiopathic true precocious puberty. J Clin Endocrinol Metab 79:415-420

120. Ross JL, Cassorla FG, Skerda MC, Valk IM, Loriaux DL, Cutler Jr GB 1983 A preliminary study of the effect of estrogen dose on growth in Turner's syndrome. N Engl J Med 309:1104-1106

121. Bourguignon JP 1988 Linear growth as a function of age at onset of puberty and sex steroid dosage: therapeutic implications. Endocr Rev 9:467-488

122. Von Puttkamer K, Bierich JR, Brugger F, Hirche W, Schönberg D 1977 Östrogentherapie bei Mädchen mit konstistutionellem Hochwuchs: Erfolg und Wirkungsweise. Dtsch Med Wochenschr 102: 983-988

123. Kuhn N, Blunck W, Stahnke N, Wiebel J, Willig RP 1977 Estrogen treatment in tall girls. Acta Paediatr Scand 66:161-167

124. Colle ML, Alperin H, Greenblatt RB 1977 The tall girl: prediction of mature height and management. Arch Dis Child 52:118-120

125. Bierich JR 1978 Estrogen treatment of girls with constitutional tall stature. Pediatrics 62:1196-1201

126. Willig RP, Christiansen D, Kuhn N, Schaefer E, Stahnke N 1980 Voraussetzungen und Ergebnisse der Östrogenbehandlung extrem grosser Mädchen. Monatsschr Kinderheilkd 128:787-788

127. Andersen H, Jacobsen BB, Kastrup KW, Krabbe S, Peitersen B, Petersen KE, Thamdrup E, Wichmann R 1980 Treatment of girls with excessive height prediction: follow-up of forty girls treated with intramuscular estradiol and progesterone. Acta Paediatr Scand 69:293-297

128. Stöver B, Kollmann F 1982 Ergebnisse der Behandlung hochwüchsiger Mädchen mit conjugierten Östrogenen. Monatsschr Kinderheilkd 130:36-40

129. Sorgo W, Scholler K, Heinze F, Heinze E, Teller WM 1984 Critical analysis of height reduction in oestrogen-treated tall girls. Eur J Pediatr 142:260-265

130. Grüters A, Heidemann $\mathbf{P}$, Schlüter $\mathbf{H}$, Stubbe $\mathbf{P}$, Weber B, Helge H 1989 Effect of different oestrogen doses on final height reduction in girls with constitutional tall stature. Eur J Pediatr 149:11-13

131. Normann EK, Trygstad O, Larsen S, Dahl-Jørgensen K 1991 Height reduction in 539 tall girls treated with three different dosages of ethinyloestradiol. Arch Dis Child 66:1275-1278

132. Brämswig JH, Von Lengerke HJ, Schmidt H, Schellong G 1988 The results of short-term (6 months) high-dose testosterone treatment on bone age and adult height in boys of excessively tall stature. Eur J Pediatr 148:104-106

133. Bhasin S, Bremner WJ 1997 Emerging issues in androgen replacement therapy. J Clin Endocrinol Metab 82:3-8

134. Gooren LJG 1994 A ten-year safety study of the oral androgen testosterone undecanoate. J Androl 15:212-215

135. Heinrich UE, Schönberg DK, Grulich-Henn J 1997 Short-term, high-dose testosterone treatment fails to reduce adult height in boys with constitutional tall stature. Eur J Pediatr 156:911-915

136. Brämswig JH, Nieschlag E, Schellong G 1984 Pituitary-gonadal function in boys after high dose testosterone treatment for excessively tall stature. Acta Endocrinol (Copenh) 107:97-103

137. Matsumoto AM 1990 Effects of chronic testosterone administration in normal men: safety and efficacy of high dosage testosterone and parallel dose-dependent suppression of luteinizing hormone, follicle-stimulating hormone, and sperm production. J Clin Endocrinol Metab 70:282-287

138. Anonymous 1990 Contraceptive efficacy of testosterone-induced azoospermia in normal men: World Health Organization Task Force on methods for the regulation of male fertility. Lancet 336: 955-959

139. Sharpe RM 1994 Regulation of spermatogenesis. In: Knobil E, Neill JD (eds) The Physiology of Reproduction, ed 2. Raven Press, New York, pp 1363-1434 
140. Cortes D, Müller J, Skakkebaek NE 1987 Proliferation of Sertoli cells during development of the human testis assessed by stereological methods. Int J Androl 10:589-596

141. De Kretser DM, McLachlan RI, Robertson DM, Wreford NG 1992 Control of spermatogenesis by follicle stimulating hormone and testosterone. Baillieres Clin Endocrinol Metab 6:335-354

142. Matsumoto AM, Bremner WJ 1987 Endocrinology of the hypothalamic-pituitary-testicular axis with particular reference to the hormonal control of spermatogenesis. Baillieres Clin Endocrinol Metab 1:71-87

143. Müller J, Skakkebaek NE 1983 Quantification of germ cells and seminiferous tubules by stereological examination of testicles from 50 boys who suffered from sudden death. Int J Androl 6:143-156

144. Steinberger E 1971 Hormonal control of mammalian spermatogenesis. Physiol Rev 51:1-22

145. Kulin HE, Frontera MA, Demers LM, Bartholomew MJ, Lloyd TA 1989 The onset of sperm production in pubertal boys: relationship to gonadotropin excretion. Am J Dis Child 143:190-193

146. Nielsen CT, Skakkebaek NE, Richardson DW, Darling JAB, Hunter WM, Jørgensen M, Nielsen A, Ingerslev O, Keiding N, Müller J 1986 Onset of the release of spermatozoa (spermarche) in boys in relation to age, testicular growth, pubic hair, and height. J Clin Endocrinol Metab 62:532-535

147. Richardson DW, Short RV 1978 Time of onset of sperm production in boys. J Biosoc Sci [Suppl 5]:15-25

148. Schaefer F, Marr J, Seidel C, Tilgen W, Scharer K 1990 Assessment of gonadal maturation by evaluation of spermaturia. Arch Dis Child 65:1205-1207

149. Barham SS, Berlin JD 1974 Fine structure and cytochemistry of testicular cells in men treated with testosterone propionate. Cell Tissue Res 148:159-182

150. Heller CG, Nelson WO, Hill IB, Henderson E, Maddock WO, Jungck EC, Paulsen CA, Mortimore GE 1950 Improvement in spermatogenesis following depression of the human testis with testosterone. Fertil Steril 1:415-420

151. Jezek D, Simunic-Banek L, Pezerovic-Panijan R 1993 Effects of high doses of testosterone propionate and testosterone enanthate on rat seminiferous tubules - a stereological and cytological study. Arch Toxicol 67:131-140

152. Tricker J, Casaburi R, Storer TW, Clevenger B, Berman N, Shirazi A, Bhasin S 1996 The effects of supraphysiological doses of testosterone on angry behavior in healthy eugonadal men: a clinical research center study. J Clin Endocrinol Metab 81:3754-3758

153. Lemcke B, Zentgraf J, Behre HM, Kliesch S, Brämswig JH, Nieschlag E 1996 Long-term effects on testicular function of highdose testosterone treatment for excessively tall stature. J Clin Endocrinol Metab 81:296-301

154. De Waal WJ, Vreeburg JTM, Bekkering F, De Jong FH, De Muinck Keizer-Schrama SMPF, Drop SLS, Weber RFA 1995 High dose testosterone therapy for reduction of final height in constitutionally tall boys: does it influence testicular function in adulthood? Clin Endocrinol (Oxf) 43:87-95

155. Bergmann M, Behre HM, Nieschlag E 1994 Serum FSH and testicular morphology in male infertility. Clin Endocrinol (Oxf) 40: 133-136

156. Karpas AE, Matsumoto AM, Paulsen CA, Bremner WJ 1983 Elevated serum follicle-stimulating hormone levels in men with normal seminal fluid analyses. Fertil Steril 39:333-336

157. Jensen TK, Andersson AM, Hjollund NH, Scheike T, Kolstad H, Giwercman A, Henriksen TB, Ernst E, Bonde JP, Olsen J, McNeilly A, Groome NP, Skakkebaek E 1997 Inhibin B as a serum marker of spermatogenesis: correlation to differences in sperm concentration and follicle-stimulating hormone levels: a study of 349 Danish men. J Clin Endocrinol Metab 82:4059-4063

158. Mauss J, Börsch G, Bormacher K, Richter E, Leyendecker G, Nocke W 1975 Effect of long-term testosterone oenanthate administration on male reproductive function: clinical evaluation, serum FSH, LH, testosterone, and seminal fluid analyses in normal men. Acta Endocrinol (Copenh) 78:373-384

159. Willig RP, Hinkel GK, Brod R, Stahnke N, Müller-Möhring G, Horn K, Schirren C 1991 Long-term side effects on testicular and pituitary function following testosterone treatment for tall stature in boys. Acta Endocrinol Suppl (Copenh) 124[1]:36 (Abstract)
160. Willig RP, Bettendorf M, Hinkel GK, Schwarz HP, Schulze W 1992 Androgen treatment of tall stature during puberty may reduce sperm quality in adult life. Horm Res 37[Suppl 4]:3 (Abstract)

161. Chehval MJ, Purcell MH 1992 Deterioration of semen parameters over time in men with untreated varicocele: evidence of progressive testicular damage. Fertil Steril 57:174-177

162. Gorelick JI, Goldstein M 1993 Loss of fertility in men with varicocele. Fertil Steril 59:613-616

163. Haans LCF, Laven JSE, Mali WPTM, Te Velde ER, Wensing CJG 1991 Testis volumes, semen quality, and hormonal patterns in adolescents with and without a varicocele. Fertil Steril 56:731-736

164. World Health Organization 1992 The influence of varicocele on parameters of fertility in a large group of men presenting to infertility clinics. Fertil Steril 57:1289-1293

165. Vine MF, Margolin BH, Morrison HI, Hulka BS 1994 Cigarette smoking and sperm density: a meta-analysis. Fertil Steril 61:35-43

166. Purvis K, Christiansen E 1993 Infection in the male reproductive tract: impact, diagnosis and treatment in relation to male infertility. Int J Androl 16:1-13

167. Yavetz H, Harash B, Paz G, Yogev L, Jaffa AJ, Lessing JB, Homonnai ZT 1992 Cryptorchidism: incidence and sperm quality in infertile men. Andrologia 24:293-297

168. Barratt CLR, Dunphy BC, Thomas EJ, Cooke ID 1988 Semen characteristics of 49 fertile males. Andrologia 20:264-269

169. Carlsen E, Giwercman A, Keiding N, Skakkebaek NE 1992 Evidence for decreasing quality of semen during past 50 years. $\mathrm{Br}$ Med J 305:609-613

170. Delemarre-Van De Waal HA 1993 Induction of testicular growth and spermatogenesis by pulsatile, intravenous administration of gonadotrophin-releasing hormone in patients with hypogonadotrophic hypogonadism. Clin Endocrinol (Oxf) 38:473-480

171. Hargreave TB 1993 Varicocele - a clinical enigma. Br J Urol 72: 401-408

172. Laven JSE 1991 The Varicocele: Experimental Animal Models and a Randomized Clinical Study in Adolescents. Ph.D. Thesis, Rijksuniversiteit, Utrecht, The Netherlands

173. Traupe H, Von Mühlendahl KE, Brämswig J, Happle R 1988 Acne of the fulminans type following testosterone therapy in three excessively tall boys. Arch Dermatol 124:414-417

174. Commentz JC, Conrad C, Stahnke N, Willig RP 1994 Priapism during testosterone treatment for reducing final height in tall stature. Horm Res 41:103 (Abstract)

175. De Waal WJ, Torn M, De Muinck Keizer-Schrama SMPF, Aarsen RSR, Drop SLS 1995 Long term sequelae of sex steroid treatment in the management of constitutionally tall stature. Arch Dis Child 73:311-315

176. Hartmann AA, Burg G 1989 Acne fulminans bei Klinefelter-Syndrom unter Testosteron: eine Nebenwirkung der Antihochwuchstherapie. Monatsschr Kinderheilkd 137:466-467

177. Fyrand O, Fiskaadal HJ, Trygstad O 1992 Acne in pubertal boys undergoing treatment with androgens. Acta Derm Venereol (Stockh) 72:148-149

178. Hinkel GK, Hanefeld M, Jaross W, Leonhardt W, Trübsbach A 1985 Effects of high doses of oestrogens and androgens on lipoproteins: observations in the treatment of excessive growth with sexual hormones. Exp Clin Endocrinol 86:17-25

179. Braunstein GD 1993 Gynecomastia. N Engl J Med 328:490-495

180. De Waal WJ 1996 Influencing the Extremes of Growth: Too Tall Too Small. Ph.D. Thesis, Erasmus Universiteit, Rotterdam, The Netherlands

181. Binder G, Grauer ML, Wehner AV, Wehner F, Ranke MB 1997 Outcome in tall stature: final height and psychological aspects in 220 patients with and without treatment. Eur J Pediatr 156:905-910

182. Goldzieher MA 1956 Treatment of excessive growth in the adolescent female. J Clin Endocrinol Metab 16:249-252

183. Trygstad O 1986 Oestrogen treatment of adolescent tall girls: short term side effects. Acta Endocrinol Suppl (Copenh) 279:170-173

184. Freed SC 1958 Suppression of growth in excessively tall girls. JAMA 166:1322-1323

185. Greenwald P, Barlow JJ, Nasca PC, Burnett WS 1971 Vaginal cancer after maternal treatment with synthetic estrogens. N Engl J Med 285:390-392

186. Herbst AL, Ulfelder H, Poskanzer DC 1971 Adenocarcinoma of 
the vagina: association of maternal stilbestrol therapy with tumor appearance in young women. N Engl J Med 284:878-881

187. Whitelaw MJ 1967 Experiences in treating excessive height in girls with cyclic oestradiol valerate: a ten year survey. Acta Endocrinol (Copenh) 54:473-484

188. Conte FA, Grumbach MM 1978 Estrogen use in children and adolescents: a survey-epidemiological aspects of estrogen use. Pediatrics 62:1091-1097

189. Crawford JD 1978 Treatment of tall girls with estrogen. Pediatrics 62:1189-1195

190. Greenblatt RB, McDonough PG, Mahesh VB 1966 Estrogen therapy in inhibition of growth. J Clin Endocrinol Metab 26:1185-1191

191. Hindmarsh PC, Brook CGD 1995 Tall stature. In: Brook CGD (ed) Clinical Paediatric Endocrinology, ed 3. Blackwell Science, Oxford, U.K., pp 195-209

192. Hanker JP, Schellong G, Schneider HPG 1979 The functional state of the hypothalamo-pituitary axis after high-dose oestrogen therapy in excessively tall girls. Acta Endocrinol (Copenh) 91:19-29

193. Hull MGR, Bromham DR, Savage PE, Barlow TM, Hughes AO, Jacobs HS 1981 Post-pill amenorrhea: a causal study. Fertil Steril $36: 472-476$

194. Münster K, Helm P, Schmidt L 1992 Secondary amenorrhoea: prevalence and medical contact - a cross-sectional study from a Danish county. Br J Obstet Gynaecol 99:430-433

195. Gold EB, Bush T, Chee E 1994 Risk factors for secondary amenorrhea and galactorrhea. Int J Fertil Menopausal Stud 39:177-184

196. Werder EA, Waibel P, Sege D, Flury R 1990 Severe thrombosis during oestrogen treatment for tall stature. Eur J Pediatr 149:389-390

197. Panteon E, Loumaye E, Maes M, Malvaux P 1988 Occurrence of prolactinoma after estrogen treatment in a girl with constitutional tall stature. J Pediatr 113:337-339

198. Grimes DA 1992 The safety of oral contraceptives: epidemiologic insights from the first 30 years. Am J Obstet Gynecol 166:1950-1954

199. Kaunitz AM 1992 Oral contraceptives and gynecologic cancer: an update for the 1990s. Am J Obstet Gynecol 167:1171-1176

200. Muntean W, Borkenstein M 1980 Haemostatic changes in tall girls treated with high doses of ethinyloestradiol. Eur J Pediatr 134:245-248

201. Blombäck M, Hall K, Ritzén EM 1983 Estrogen treatment of tall girls: risk of thrombosis? Pediatrics 72:416-419

202. Weimann E, Brack C 1996 Severe thrombosis during treatment with ethinylestradiol for tall stature. Horm Res 45:261-263

203. Deleted in proof

204. Weninger M, Frisch H, Schober E, Strobl W, Widhalm K 1987 Increase of serum lipids and serum lipoproteins in girls under therapy with estrogen and norethisteron for height reduction. Acta Paediatr Scand 76:500-503

205. Rushton L, Jones DR 1992 Oral contraceptive use and breast cancer risk: a meta-analysis of variations with age at diagnosis, parity and total duration of oral contraceptive use. Br J Obstet Gynaecol 99: 239-246

206. Melmed S 1990 Acromegaly. N Engl J Med 322:966-977

207. Evain-Brion D, Garnier P, Blanco-Garcia M, Job JC 1984 Studies in constitutionally tall adolescents. II. Effects of bromocriptine on growth hormone secretion and adult height prediction. J Clin Endocrinol Metab 58:1022-1026

208. Brion DE, Murrieta D, Job JC 1985 Bromocriptine treatment in tall adolescents: two years of clinical experience. Horm Res 22:107-109
209. Bartolotta E, Acquafredda A, Evain-Brion D, Job JC 1987 Effets de la bromocriptine sur la maturation osseuse chez les adolescents de grande taille: comparaison des méthodes de Greulich et Pyle et de Tanner TW 2 RUS. Arch Fr Pediatr 44:181-183

210. Evain Brion D, Repellin AM, Schimpff RM 1986 Effect of bromocriptine treatment on circulating somatomedins in tall adolescents. Acta Paediatr Scand 75:106-110

211. Schwarz HP, Joss EE, Zuppinger KA 1987 Bromocriptine treatment in adolescent boys with familial tall stature: a pair-matched controlled study. J Clin Endocrinol Metab 65:136-140

212. Schoenle EJ, Theintz G, Torresani T, Prader A, Illig R, Sizonenko PC 1987 Lack of bromocriptine-induced reduction of predicted height in tall adolescents. J Clin Endocrinol Metab 65:355-358

213. Van Der Werff Ten Bosch JJ, Bot A, Steendijk R, Kok I, Wolters HJ 1988 Bromocriptine does not accelerate skeletal maturation of tall boys. Neth J Med 32:15-19

214. Bertherat J, Bluet-Pajot MT, Epelbaum J 1995 Neuroendocrine regulation of growth hormone. Eur J Endocrinol 132:12-24

215. Hindmarsh PC, Pringle PJ, Di Silvio L, Brook CGD 1990 A preliminary report on the role of somatostatin analogue (SMS 201-995) in the management of children with tall stature. Clin Endocrinol (Oxf) 32:83-91

216. Tauber MT, Tauber JP, Vigoni F, Harris AG, Rochicchioli P 1990 Effect of the long-acting somatostatin analogue SMS 201-995 on growth rate and reduction of predicted adult height in ten tall adolescents. Acta Paediatr Scand 79:176-181

217. Nilsson NO, Aronson S, Hagenäs L, Ritzén M 1991 Effects of octreotide (SMS 201-995) on growth rate and growth hormone levels in two children with tall stature. Acta Paediatr Scand Suppl 372:165 (Abstract)

218. Hindmarsh PC, Pringle PJ, Stanhope R, Brook CGD 1995 The effect of a continuous infusion of a somatostatin analogue (octreotide) for two years on growth hormone secretion and height prediction in tall children. Clin Endocrinol (Oxf) 42:509-515

219. Lamberts SWJ 1991 Somatostatin analogs: their role in the treatment of growth hormone hypersecretion and excessive body growth. Growth Regul 1:3-10

220. Plaschaert VFP, Van Der Eijken JW, Odink RJH, Delemarre HA, Caron JJ 1997 Bilateral epiphysiodesis around the knee as treatment for excessive height in boys. J Pediatr Orthop 6:212-214

221. Nordsletten L, Holm I, Steen H, Follerås G, Bjerkreim I 1992 Bilateral femoral shortening for unaccepted tallness. J Bone Joint Surg Br 74:406-408

222. Deleted in proof

223. Sassolas G 1995 Medical therapy with somatostatin analogues for acromegaly. Eur J Endocrinol 133:675-677

224. Ocampo-Lim B, Guo W, DeMott-Friberg R, Barkan AL, Jaffe CA 1996 Nocturnal growth hormone (GH) secretion is eliminated by infusion of GH-releasing hormone antagonist. J Clin Endocrinol Metab 81:4396-4399

225. Chen WY, Chen NY, Yun J, Wagner TE, Kopchick JJ 1994 In vitro and in vivo studies of antagonistic effects of human growth hormone analogs. J Biol Chem 269:15892-15897

226. Sundström M, Lundqvist T, Rödin J, Giebel LB, Milligan D, Norstedt G 1996 Crystal structure of an antagonist mutant of human growth hormone, G120R, in complex with its receptor at 2.9 Å resolution. J Biol Chem 271:32197-32203 